UMEÅ UNIVERSITY MEDICAL DISSERTATIONS

New series No 465 - ISSN 0346 - 6612

From the Departments of Rheumatology and Medicine, University of Umeå, Umeå, Sweden

\title{
ON INFLAMMATION AND CARDIOVASCULAR DISEASE IN PATIENTS WITH RHEUMATOID ARTHRITIS
}

\begin{abstract}
AKADEMISK AVHANDLING
som med vederbörligt tillstånd av Rektorsämbetet vid Umeå Universitet för avläggande av medicine doktorsexamen kommer att offentligen försvaras i sal 260, By 3A, 2 tr, Norrlands Universitetssjukhus, Umeå, fredagen den 8 mars 1996 kl 09.00
\end{abstract}

av

Solveig Wållberg Jonsson

Umeå 1996 


\section{ABSTRACT}

\section{ON INFLAMMATION AND CARDIOVASCULAR DISEASE IN PATIENTS WITH RHEUMATOID ARTHRITIS}

Solveig Wållberg Jonsson, Departments of Rheumatology and Medicine, University of Umeå, S-901 85 Umeå.

Patients with rheumatoid arthritis (RA) have a shorter life span than the general population. An increased death due to cardiovascular disease (CVD) has been reported. RA is characterized by synovitis and joint destruction accompanied by an acute phase reaction and systemic features. The present work investigates the epidemiology of CVD in patients with RA in the county of Västerbotten and the influence of inflammation on lipid metabolism and haemostasis.

In a retrospective cohort study on 606 RA patients, the overall mortality was significantly higher than in the general population, with an excess death rate for CVD and for ishemic heart diseae (IHD) in both sexes. Multiple Cox regression, showed that male sex, higher age at disease onset and cardiovascular event increased the risk for death. Male sex, high age at disease onset and hypertension increased the risk for cardiovascular event. Diabetes mellitus, treatment with corticosteroids, disease modifying antirheumatic drugs and postmenopausal estrogen neither influenced survival nor the risk of cardiovascular event.

In 93 patients with active RA, the levels of cholesterol, high density- (HDL) and low density (LDL) lipoprotein cholesterol were significantly lower, and Lipoprotein(a) was significantly higher compared to controls. In a follow-up on 53 patients, a relation between the change of $L p(a)$ and acute phase proteins was found only in patients with high levels of $L p(a)$.

Preheparin lipoprotein lipase (LPL) activity and mass were significantly decreased in 17 postmenopausal women with active RA. Preheparin LPL mass correlated inversely to several acute phase proteins and interleukin-6. Low levels of LPL mass may implicate increased hepatic clearence but also increased macrophage ingestion of lipoproteins via the LDL receptor-related protein (LRP).

Haemostasis of the circulation was investigated in 74 of the 93 patients with active RA. In patients with extraarticular disease, the release of tissue plasminogen activator (tPA) was significantly decreased, and its inhibitor (PAI-1) was significantly increased compared to patients with nonsystemic disease, implicating hypofibrinolysis. In a two year follow-up, patients with thromboembolic events had significantly elevated levels of von Willebrand factor, PAI-1, triglycerides and haptoglobin compared to event-free patients.

In $29 \mathrm{RA}$ patients and 18 spondylarthropathy patients with gonarthritis, radiological joint destruction correlated to PAI-1 antigen in synovial fluid and, inversely, to plasminogen. A relationship between activation of fibrin degrading proteolytic enzymes and joint destruction was implicated.

In conclusion, several processes involved in lipid metabolism and haemostasis are influenced in active RA. In view of the increased death rate due to CVD, an efficient control of inflammation should be important, not only for reducing joint destruction, but also for reducing systemical atherogenic and thrombogenic effects.

Key words: Rheumatoid arthritis, mortality, cardiovascular disease, ischemic heart disease, inflammation, lipids, $\mathrm{Lp}(\mathrm{a})$, haemostasis, fibrinolysis, atherogenesis, thrombogenesis. 
UMEA UNIVERSITY MEDICAL DISSERTATIONS

New series No 465 - ISSN 0346 - 6612

From the Departments of Rheumatology and Medicine, University of Umeå, Umeå, Sweden

\section{ON INFLAMMATION AND CARDIOVASCULAR DISEASE IN PATIENTS WITH RHEUMATOID ARTHRITIS}

Solveig Wållberg Jonsson

Umeå 1996 
Copyright $\odot$ Solveig Wållberg Jonsson ISBN 91-7191-154-5

Printed in Sweden by

Solfjädern Offset AB Umeå 1996 


\section{CONTENTS}

ABBREVIATIONS $\quad 2$

ABSTRACT $\quad 3$

$\begin{array}{ll}\text { LIST OF ORIGINAL PAPERS } & 4\end{array}$

INTRODUCTION $\quad 5$

BACKGROUND $\quad 5$

The inflammatory reaction

Life expectancy

The atherothrombotic process

Traditional cardiovascular risk factors in RA

Potential cardiovascular risk factors, related to the inflammation in active RA

Pharmacological treatment

OBJECTIVES

SUBJECTS, INCLUSION CRITERIA AND STUDY DESIGN

Paper I

Paper II, III and V

Paper IV

Paper VI

METHODS

Laboratory procedures

Lipids, lipoproteins and apolipoproteins

Lipoprotein lipase

Fibrinolytic components

von Willebrand factor

Inflammatory variables

Cytokines

Radiography

Oral fat load

STATISTICS

23

ETHICAL ASPECTS $\quad 24$

MAIN RESULTS 24

Epidemiology

Atherogenesis

Lipids

$\mathrm{Lp}$ (a)

LPL

Hemostatic factors

in the circulation

DISCUSSION in the joint

Epidemiology

Atherogenesis

Haemostasis

CONCLUSION AND FINAL REMARKS $\quad 35$

$\begin{array}{ll}\text { ACKNOWLEDGEMENTS } & 37\end{array}$

$\begin{array}{lr}\text { REFERENCES } & 39\end{array}$

$\begin{array}{lll}\text { PAPERS I } & 55\end{array}$

II 76

III $\quad 81$

IV 90

V 107

VI 116 


\section{ABBREVIATIONS}

CVD cardiovascular disease

IHD ischemic heart disease

TE thromboembolic event

SMR standardized mortality ratio

vWF von Willebrand factor

tPA tissue plasminogen activator

pro-uPA pro-urokinase

PAI plasminogen activator inhibitor

Lp(a) lipoprotein (a)

LDL low density lipoprotein

VLDL very low density lipoprotein

HDL high density lipoprotein

LPL lipoprotein lipase

LRP low density lipoprotein receptor-related protein $/ \alpha_{2}$-macroglobulin receptor

TNF- $\alpha$ Tumor Necrosis Factor- $\alpha$

II interleukin

aCL anticardiolipin antibodies

DMARD disease modifying antirheumatic drug(s)

NSAID nonsteroid anti-inflammatory drug(s)

ASA acetylsalicylate

HRT hormone replacement therapy

SpA spondylarthropathy 


\section{ABSTRACT}

\section{ON INFLAMMATION AND CARDIOVASCULAR DISEASE IN PATIENTS WITH RHEUMATOID ARTHRITIS}

Solveig Wållberg Jonsson, Departments of Rheumatology and Medicine, University of Umeå, S-901 85 Umeå.

Patients with rheumatoid arthritis (RA) have a shorter life span than the general population. An increased death due to cardiovascular disease (CVD) has been reported. RA is characterized by synovitis and joint destruction accompanied by an acute phase reaction and systemic features. The present work investigates the epidemiology of CVD in patients with RA in the county of Västerbotten and the influence of inflammation on lipid metabolism and haemostasis.

In a retrospective cohort study on $606 \mathrm{RA}$ patients, the overall mortality was significantly higher than in the general population, with an excess death rate for CVD and for ishemic heart diseae (IHD) in both sexes. Multiple Cox regression, showed that male sex, higher age at disease onset and cardiovascular event increased the risk for death. Male sex, high age at disease onset and hypertension increased the risk for cardiovascular event. Diabetes mellitus, treatment with corticosteroids, disease modifying antirheumatic drugs and postmenopausal estrogen neither influenced survival nor the risk of cardiovascular event.

In 93 patients with active RA, the levels of cholesterol, high density- (HDL) and low density (LDL) lipoprotein cholesterol were significantly lower, and Lipoprotein(a) was significantly higher compared to controls. In a follow-up on 53 patients, a relation between the change of $\mathrm{Lp}(\mathrm{a})$ and acute phase proteins was found only in patients with high levels of $\mathrm{Lp}(\mathrm{a})$.

Preheparin lipoprotein lipase (LPL) activity and mass were significantly decreased in 17 postmenopausal women with active RA. Preheparin LPL mass correlated inversely to several acute phase proteins and interleukin-6. Low levels of LPL mass may implicate increased hepatic clearence but also increased macrophage ingestion of lipoproteins via the LDL receptor-related protein (LRP).

Haemostasis of the circulation was investigated in 74 of the 93 patients with active RA. In patients with extraarticular disease, the release of tissue plasminogen activator (tPA) was significantly decreased, and its inhibitor (PAI-1) was significantly increased compared to patients with nonsystemic disease, implicating hypofibrinolysis. In a two year follow-up, patients with thromboembolic events had significantly elevated levels of von Willebrand factor, PAI-1, triglycerides and haptoglobin compared to event-free patients.

In $29 \mathrm{RA}$ patients and 18 spondylarthropathy patients with gonarthritis, radiological joint destruction correlated to PAI-1 antigen in synovial fluid and, inversely, to plasminogen. A relationship between activation of fibrin degrading proteolytic enzymes and joint destruction was implicated.

In conclusion, several processes involved in lipid metabolism and haemostasis are influenced in active RA. In view of the increased death rate due to CVD, an efficient control of inflammation should be important, not only for reducing joint destruction, but also for reducing systemical atherogenic and thrombogenic effects.

Key words: Rheumatoid arthritis, mortality, cardiovascular disease, ischemic heart disease, inflammation, lipids, Lp(a), lipoproteinlipase, haemostasis, fibrinolysis, atherogenesis, thrombogenesis. 


\section{LIST OF ORIGINAL PAPERS}

This thesis is based on the following papers which will be referred to by their roman numerals:

I Wållberg Jonsson S, Öhman M-L, Rantapää Dahlqvist S. Cardiovascular morbidity and mortality in rheumatoid arthritis in Northern Sweden. Submitted.

II Rantapää Dahlqvist S, Wållberg Jonsson S, Dahlén G. Lipoprotein(a), lipids and lipoproteins in patients with rheumatoid arthritis. Ann Rheum Dis 1991; 50: 366-8

III Wållberg Jonsson S, Dahlén G, Uddhammar A, Rantapää Dahlqvist S. Lipoprotein(a) in relation to acute phase reaction in patients with rheumatoid arthritis and polymyalgia rheumatica. Scand J Clin Lab Invest 1995; 55: 309-15

IV Wållberg Jonsson S, Dahlén G, Johnson O, Olivecrona G, Rantapää Dahlqvist $S$. Lipoprotein lipase in relation to inflammatory activity in rheumatoid arthritis. Submitted.

V Wållberg Jonsson S, Dahlén G, Nilsson TK, Rånby M, Rantapää Dahlqvist $\mathrm{S}$. Tissue plasminogen activator, plasminogen activator inhibitor-1 and von Willebrand Factor in rheumatoid arthritis. Clinical Rheumatol 1993;12: 318-24.

VI Wållberg Jonsson S, Rantapää Dahlqvist S, Nordmark L, Rånby M. Mobilization of fibrinolytic enzymes in synovial fluid and plasma of rheumatoid arthritis and spondylarthropathy. Relation to radiologic destruction. Submitted.

Papers II, III and V are printed with kind permisson by the publishers. 


\section{INTRODUCTION}

Rheumatoid arthritis (RA) is a chronic inflammatory disease of unknown etiology. It is a systemic disease with marked local inflammation mainly in the synovial tissue of joints, tendon sheets and bursae which eventually leads to joint destruction. RA has generally been regarded as a "nonfatal" disease in most patients (1). Early studies reported decreased death due to cardiovascular disease (CVD). However, during the last decades a different view has emerged. A great number of studies have reported a shortened lifespan in RA and several authors have reported an increased cardiovascular death in RA. These facts may seem somewhat puzzling since patients with RA have few traditional cardiovascular risk factors and moreover they consume NSAID more or less regularly.

The present work was directed at investigating the role played by lipid metabolism and haemostasis in inflammatory active RA with special reference to the progression of CVD. The epidemiology of CVD in RA in Västerbotten, a county in Northern Sweden, was also investigated.

\section{BACKGROUND}

\section{THE INFLAMMATORY REACTION IN RA}

The initiation and progress of synovitis and subsequent matrix destruction is the result of a complicated interaction between several types of cells and their products (2-3). The still predominant theory is that a T-cell dependent process interacts with synoviocytes, mainly macrophages and fibroblast-like cells $(2,4)$.

Early in the inflammatory process the synovial cells start proliferating and producing cytokines, such as tumour necrosis factor- $\alpha$ (TNF- $\alpha$ ) and interleukin-1 (IL-1). Stimulated vascular endothelial cells express adhesion molecules, mainly intracellular adhesion molecule-1 (ICAM-1), but also Eselectin and vascular cell adhesion molecules (VCAM-1) (5). These molecules make it possible for leucocytes, mainly monocytes and lymphocytes, to enter the perivascular synovial tissue. The triggering event of a cellular as well as a humoral immune responce is believed to be the presentation of a yet unknown antigen to activated CD4 positive T-lymphocytes, by class II expressing antigen presenting cells in the synovial membrane. Thus activated antigen recognizing T-lymphocytes cause further activation and differentiation of lymphocytes via immunoregulatory cytokines such as interleukin-2 and interferon- $\gamma(3)$

Along the cellular line, synoviocytes are stimulated to production of destroying 
enzymes, prostaglandins and cytokines but also agents such as free oxygen radicals and nitric oxide. The growth factors induce angiogenesis and fibrosis $(2,3)$. The synovial membrane is transformed into a destructive pannus, growing over the cartilage. IL-1 and TNF- $\alpha$ activate subchondral osteoclasts, leading to bone erosions, and chondrocytes, leading to production of proteolytic ezymes such as collagenase and stromelysin, and granulocyte chemotactic cytokines $(2,3)$.

The humoral immune response is mediated by B-lymphocytes, which produce antibodies, mainly IgM rheumatoid factor. This provides the conditions for formation of immune complexes and complement activation in the synovial fluid (2). Phagocyting granulocytes release their contents of matrix degrading enzymes, which further enhance vasodilatation, extravasation and chemotaxis. The clotting cascade is activated, leading to intraarticular and synovial fibrin deposition which in turn leads to activation of the fibrinolytic system. Its end product, plasmin, is a potent activator of collagenase and stromelysin (2).

Lately, the concept of joint destruction as a T-cell nondependent, synoviocyte driven process, originally presented by Fassbender, (6) has regained support. According to this hypothesis, synovial inflammation and joint destruction are distinct pathophysiological entities (7). The appearence of proliferating transformed synoviocytes that produce matrix-degrading cathepsins and proteases is suggested to be due to activation of specific genes, protooncogenes such as myb, myc, ras and fos (8). Oncogenes play a role in the initiation and control of cell proliferation, production of destructive enzymes and in apoptosis. Inhibition of cell apoptosis is one mechanism suggested to maintain protease production and concomitant joint destruction in RA (8)

Although joints are primarily affected, systemic consequences reflected by the acute phase response (9) are also apparent in RA (10). During active disease, pro-inflammatory systemically active cytokines are produced within the joints and found in the serum. These cytokines are capable of inducing the hepatic synthesis of acute phase proteins ( Fig 1) (10). Systemic features of the disease are reactive anemia, fatigue, malaise, weight loss, subfebrility, low grade myositis and gradual osteoporosis. The cytokine mainly responsible for these systemic reactions is interleukin- 6 (IL-6), but IL-1, TNF- $\alpha$ and other cytokines are also involved $(3,10)$. Other extraarticular manifestations are rheumatoid nodules, scleritis, Sjögrens syndrome, serositis and neuropathy. 


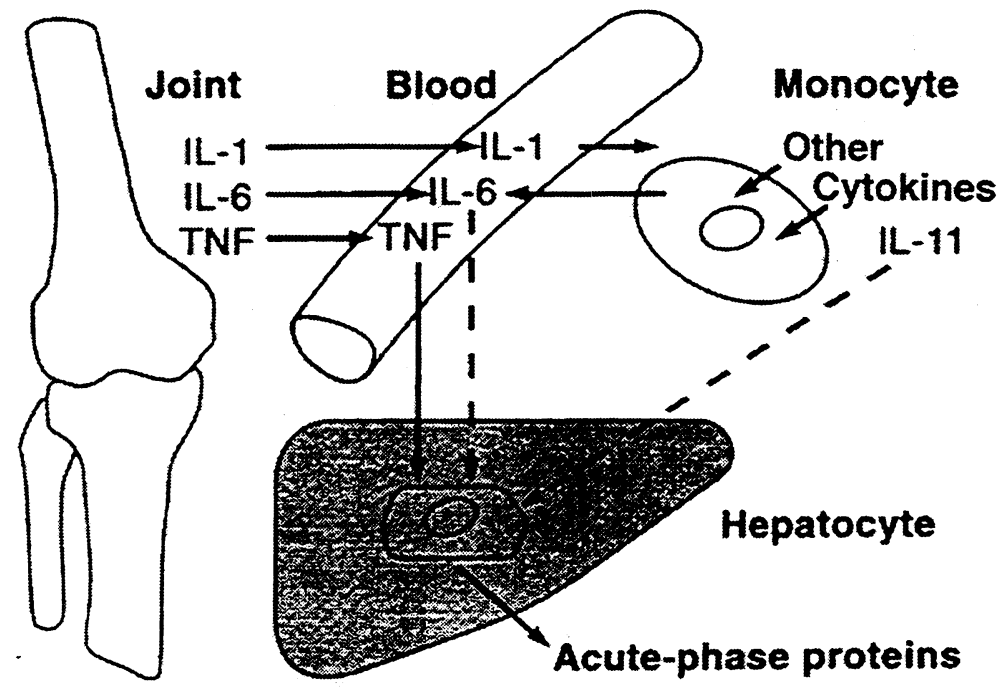

Fig. 1. Schematic diagram of cytokine response to inflammation in the joint. After Emery (10)

Some of these features are regarded to be mediated by vasculitis, in which immune complexes play a pathogenetic role, but factors such as the genetic background, macrophages, T-lymphocytes and high levels of immunoglobulin A are also of importance for the extraarticular manifestations seen in RA (11). RA vasculitis has been considered to be a rare condition. The reported prevalence has varied substantially depending on which clinical and pathological criteria are used to define vasculitis (12). Subclinical vasculitis is, however, a widespread feature with reported prevalences of about $20-30 \%$ of RA patients $(13,14)$

Metabolic changes, probably related to the disease activity and involving various physiological mechanisms, occur during the disease. Several authors have described changes in the lipid metabolism (15-18) and a reduced carbohydrate tolerance $(19,20)$. Furthermore, altered serum levels of essential metals such as iron, zink, copper, magnesium and manganese have been described in chronic inflammatory processes (21). Altered intracellular stores of calcium and magnesium $(22)$, low serum levels of micronutrients $(23,24)$ and raised levels of homocystein (25) have been reported. 


\section{LIFE EXPECTANCY}

A great number of studies have reported a shortened life span in RA. Generally, hospital-based materials (26-38) reveal standardized mortality ratios (SMR) in the range of 1.3-2.5 but figures as high as 3.0 have been reported (39-40). In population-based studies the excess death rates are somewhat lower (SMR 1.16-1.37), but still significantly higher than in controls $(41,42)$, except for in one study (43). Similar results were found in a study on just female RA patients (44). The reported excess mortality in RA is equivalent to a shortening of the life span by $3-18$ years (1).

Several underlying causes of death are found more frequently in RA; the most commonly reported cause being skeletomuscular disease, i.e. the disease itself. Other causes contributing to the excess mortality are infections $(27,31,32,34$, $36,39)$, renal diseases $(29,32,34,36,39)$, respiratory diseases $(29,39)$ and gastrointestinal diseases $(29,31,34-36)$. The reports on the frequency of malignancies are contradictory $(29,32,34)$.

Cardiovascular disease (CVD) is, as in the general population, the most common cause of death in RA and is responsible for roughly half of all deaths. Two early studies reported a decreased death due to CVD $(26,27)$ and the rather general intake of nonsteroid inflammatory drugs (NSAID) was suggested to provide a protection (45). However, there are now numerous reports on an increased cardiovascular mortality in $\mathrm{RA}(28,29,32,34,39,42,44)$. Some authors $(29,39,44)$ have even reported higher mortality due to ischemic heart diseases (IHD) in RA compared to the general population while others have found the opposite $(26,46)$ or equivalent rates $(32,43)$. In Table I data from several studies on mortality in RA, with special reference to CVD and IHD, are summerized .

Morbidity studies are scarce, but in a study from 1962, Cathcart \& Spodick (47) reported a significantly elevated incidence of heart diseases with a high incidence of coronary artery disease in patients with RA, compared to controls. Data based on interviews have indicated similar results $(48,49)$. 
Table I. Studies on cardiovascular mortality in RA. Setting and standardized mortality ratio (SMR) concerning death due to cardiovascular disease (CVD), ischemic heart disease (IHD) and total mortality according to available data in each report.

SMR

\begin{tabular}{llll}
\cline { 2 - 4 } Author & CVD & IHD & Total \\
\hline Uddin et al 1970(27) & $0.73 / 1.05^{\dagger}$ & & 1.3 \\
Isomäki et al 1975(28) & 1.63 & & 1.77 \\
Monson \& Hall 1976(29) & 1.78 & 1.99 & 1.86 \\
Linos et al 1980 (43)* & & 1.02 & 1.16 \\
Lewis et al 1980(33) & & 1.23 & 1.13 \\
Allebeck 1982 (34) & 1.45 & & 2.48 \\
Prior et al 1984 (39) & 2.4 & 2.1 & 3.0 \\
Vandenbroucke et al 1984 (36) & 0.9 & & \\
Mutru et al 1985 (32) & 1.39 & 1.14 & 1.64 \\
Jacobsson et al 1993 (42)* & 1.77 & & 1.28 \\
Myllykangas-Luosujärvi 1995 (44)*1 1.34 & 1.51 & 1.37 \\
& & &
\end{tabular}

${ }^{*}$ community settings. ${ }^{\dagger}$ male/female ${ }^{1}$ females only

\section{THE ATHEROTHROMBOTIC PROCESS}

Although knowledge about the atherothrombotic process is still incomplete, the prevalent consensus of this is discussed below.

The progression of the atherosclerotic plaque has much in common with the immunologic process (50) and has recently been reviewed by Ross (51). The process, which takes place underneath an intact endothelium, is considered to be initiated when liporoteins, predominantly low density lipoprotein (LDL), penetrate the endothelium and become oxidized. Factors that may enhance this process are high cholesterol levels, hypertriglyceridemia and hypertension. Antioxidative substances may be protective by inhibition of LDL-oxidization. In the next step monocytes and lymphocytes bind to activated endothelial cells, which express VCAM and other adhesions molecules, and penetrate into the intima. Monocytes transform to macrophages, ingest large amounts of lipid and turn into "foam cells". Macrophages lack LDL receptors but can ingest oxidized LDL via the so called scavenger receptor (52), a process that lacks a 
feed back system. Enhanced oxidization of lipoproteins by free oxygen radicals derived from activated macrophages may, as it does in vitro, facilitate foam cell formation (50). Another possible uptake mechanism is via the LDL receptor related protein/ $\alpha_{2}$ macroglobulin receptor (LRP) (53) which was recently demonstrated on macrophages in atheromatous plaques (54). Foam cell rupture causes extra- as well as intracellular lipid accumulation. Under influence of oxidized LDL, growth factors and other cytokines, smooth muscle cells migrate from the media into the intima. The smooth muscle cells dedifferentiate to fibroblast-like cells, which produce connective tissue matrix. A fibrous plaque evolves containing a central necrosis, lipid accumulated in foam cells and extracellular tissue, and a fibromuscular cap composed of connective tissue and embedded muscle cells (51).

The purpose of the entire process may actually be preventive. Macrophages may present the antigen, possibly celltoxic oxidized LDL (55) or heat shock protein (56) to the T-lymphocytes for the purpose of scavenging it. Some ten percent of the leucocytes of the plaque are T-lymphocytes and a substantial proportion of these T-lymphocytes, and of the macrophages, are activated. In addition, macrophage- and T-cell derived cytokines have been isolated in the plaque (50). The inflammatory reaction and concomitant plaque growth may thus be a side effect of an adequate, antigen triggered immunologic response.

Rupture of the fibromuscular cap is probably the most important cause of sudden rapid plaque progression, responsible for acute coronary disease. Most prone to rupture are soft plaques, rich in extracellular lipids and macrophages. The macrophages may release matrix degrading enzymes that enhance the rupture of the plaque $(57,58)$. Activated platelets adhere to the lesion and aggregate resulting in primary haemostasis. The endothelial injury causes macrophage expression of a tissue factor. The tissue factor is the key trigger for induction of the coagulation system. The von Willebrand factor (vWF) stabilizes factor VIII, one of the components of the coagulation cascade. vWF also mediates bridging of the platelets to the vessel wall and between platelets (59). Thrombin, the end product of the protelytic cascade, converts fibrinogen to fibrin. The clot, consisting of blood platelets, erythrocytes and fibrin, is further stabilized by cross-linking of fibrin. Arterial thrombs are more platelet rich than venous thrombs, which contain more fibrin and erythrocytes.

The fibrinolytic system balances both the arterial and the venous thromb formation. Reviews on this subject are Bachmann (60) and Wiman and Hamsten (61). The plasminogen activator of tissue type (tPA), and urokinase (uPA), both products of the endothelium, convert the proenzyme plasminogen to proteolytically active plasmin. The predominant activator in the circulation is tPA (62). Plasmin degrades fibrin resulting in split products, of which .D-dimer 
is the most specific. The main inhibitors of the fibrinolytic system are plasminogen activator inhibitor 1 (PAI-1) (63) which inhibits the plasminogen activators, and $\alpha_{2}$-antiplasmin, which inhibits plasmin (Fig 2) (61). Plasminogen activator inhibitor-2 (PAI-2)(64) inhibits mainly urokinase and is usually not detected in plasma.

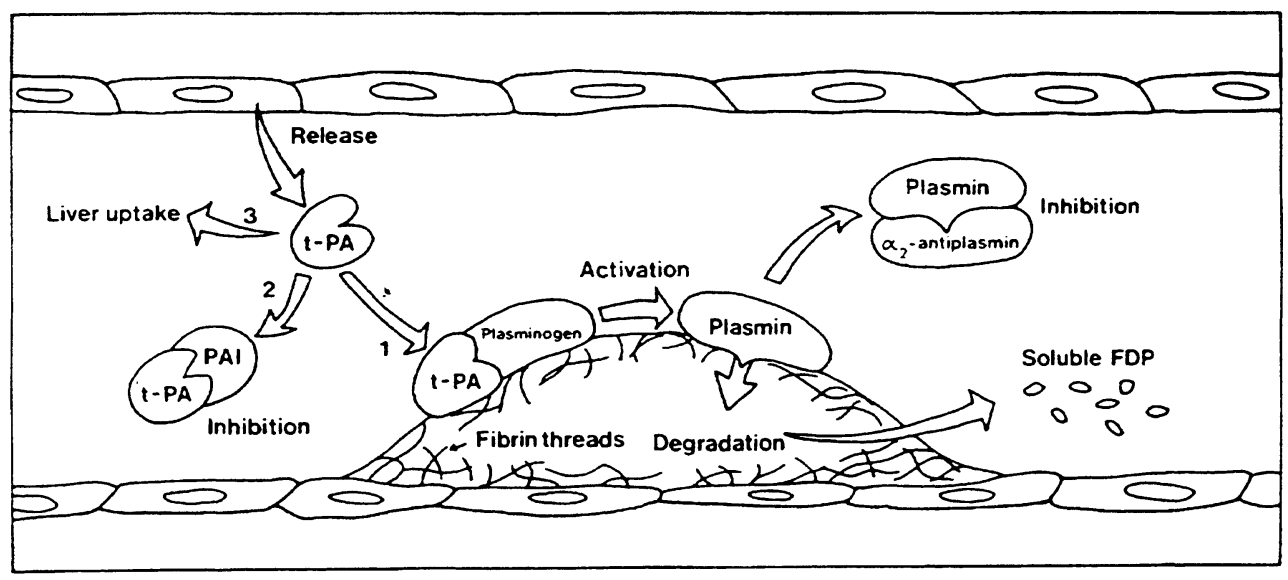

Fig 2. A schematic presentation of mechanisms and regulation of physiologic fibrinolysis. After Wiman and Hamsten (61)

\section{TRADITIONAL CARDIOVASCULAR RISK FACTORS IN RA.}

The relationship between increased diastolic blood pressure and risk of myocardial infarction (MI) and of stroke, is well known (65). In a recent report by Wolfe et al (31) on 2785 patients with RA, mean blood pressure was found to have a weak but significant predictive effect on mortality. There is, however, little data available concerning the prevalence of hypertension in RA populations. One study reported substantially lower systolic and diastolic blood pressure in RA compared to controls (66) while another found equal incidences of hypertension in RA and controls (47). Judging from patients with SLE, Kaplan et al recently hypothesized that HLA DR4 or a linked gene may be protective against nephritis as well as hypertension (67).

Diabetes mellitus increases the risk for CVD dramatically (68). HLA DR4 is associated with insulin dependent diabetes mellitus as well as with RA, which gives a theoretical basis for an association between these two chronic diseases. However, Hakala et al (69) found the same incidence of insulin dependent diabetes in RA as in the general population. Svenson et (20) al demonstrated an 
impaired glucose handling which was related to a reduced insulin sensitivity and inversely related to the acute phase reaction. The impaired glucose handling was normalized when disease activity was reduced by corticosteroid treatment. (70).

The relationship between smoking and cardiovascular mortality (71) and stroke (72) is hardly questioned. As for hypertension, smoking predicted mortality in the study by Wolfe et al (31). However, data on the prevalence of smoking in RA populations is scarce. Hazes et al found that $33 \%$ of patients with RA were smokers compared to $48 \%$ of the controls (73). On the other hand a weak association between smoking and incidence of seropositive RA has been reported (74). Heliövara et al (75) found that smoking predicted seropositive $\mathrm{RA}$ in males.

Obesity, as measured by waist-to-hip ratio, is another riskfactor for IHD and stroke (76). Although not statistically significant, Heliövara et al found an inverse relationship between body mass index (BMI) and risk of seropositive RA (75) while Voigt et al found the opposite (74). However, BMI had no predictive value for death in patients with RA (31).

An association between inactivity and IHD (77) as well as a protective effect of physical activity on stroke in men (78) has been reported. Although there is no direct evidence, it is plausible to assume that patients with RA due to their physical impairment are less active than the general population.

In conclusion, available data concerning many established risk factors do not show any apparent atherogenic pattern in RA. Several processes in active inflammatory disease may, however, provide a risk for CVD.

\section{POTENTIAL CARDIOVASCULAR RISK FACTORS RELATED TO THE INFLAMMATION IN ACTIVE RA}

\section{THE ACUTE PHASE REACTION}

Fibrinogen, one of the main determinants of the acute phase reaction, is, together with globulins, regarded to determine the plasma viscosity (79). High levels of fibrinogen are associated with $\mathrm{MI}$ and stroke (80). This was recently further discussed by Eliasson (81). There are to my knowledge no reports on the relation between the levels of fibrinogen and CVD in RA.

Thrombocytosis is another feature of the inflammatory reaction in active rheumatoid disease (82). In one study on healthy men, the blood platelet count 
was a strong and independent predictor of mortality due to coronary heart disease (83). In another study, platelet aggregation was found to be normal in patients with secondary thrombocytosis (84). However, although other rheumatoid conditions were represented, none of these patients had RA.

\section{ENDOTHELIAL FACTORS}

Several endothelially-produced factors are important in haemostasis. The vWF influences the platelet function and the coagulation cascade. Raised levels of vWF have been reported in CVD $(85,86)$. The tPA and PAI-1 are key components of the fibrinolytic system (60) (Fig 2). Interest in the fibrinolytic system has grown in the last decade since several studies have shown a relationship between a reduced fibrinolytic activity and CVD $(61,87)$. Vasculitis provides conditions for vascular endothelial cell injury and concomitantly influence the endothelially-produced factors. Thus, it is not surprising that an altered fibrinolysis and variations of the different components of the haemostatic system have been reported in various connective tissue diseases $(88,89)$ including RA $(90-93)$. A thorough review has been published by Hart \& Fritzler (94). In a joint disease such as RA, the impact of a disturbed fibrinolysis may be even more important for processes other than the haemostasis. The fibrinolysis is involved in tissue destruction, angiogenesis, macrophage migration and inflammation (95), factors which are of particular interest in the target tissue of the rheumatoid disease, i.e. the joint matrix. Thus, interest has lately been focused on fibrinolysis in the RA joint (96-99).

\section{METABOLIC FACTORS}

Hypercholesterolemia is considered to be one of the established risk factors for cardiovascular disease. A decrease in LDL cholesterol has been shown to decrease the incidence of MI both in patients with coronary artery disease (100) and in healthy individuals (101). HDL has a protective effect on $\mathrm{HHD}$ (102). An independent relation between elevated postprandial triglyceride levels and coronary heart disease (103) has also been established. In active RA, however, a low total cholesterol level was demonstrated already in 1963 (104). Since then several other authors have reported lower total cholesterol levels, and lower levels of cholesterol of all lipoprotein classes [HDL, LDL, very low density lipoprotein (VLDL)] $(16,17)$ or of some of them (LDL, HDL) $(18,15)$, in active disease compared to controls. Low triglyceride levels have been reported totally and in all lipoprotein classes (16) or in VLDL and HDL (17). Most of these authors report normalizing, i.e. raising lipid levels, with decreasing disease activity. The lipid pattern in active RA is thus not apparently atherogenic. 
An increased clearence of triglycerides was demonstrated in intravenous fat tolerance tests (IVFTT) $(16,17)$ despite low levels of the triglyceride metabolizing enzyme, lipoprotein lipase (LPL) in adipose and muscle tissue (17). An increased elimination of intermediate forms of lipoproteins via macrophages/scavenger receptors was suggested as one possible explanation for CVD in RA (17).

Lipoprotein (a) $[\mathrm{Lp}(\mathrm{a})]$ was discovered to be identical to the pre- $\beta-1$ lipoprotein and thus highly atherogenic (105). It is a cholesterol rich, LDL like lipoprotein which has shown an independent association to $\operatorname{IHD}(106,107)$. Because of its structural similarity to plasminogen, $\mathrm{Lp}(\mathrm{a})$ has been proposed to exert much of its harmful effect via interference in normal thrombolysis $(108,109)$. Maeda et al (110) suggested that $\mathrm{Lp}(\mathrm{a})$ had an acute phase character and Ledue et al (111) found a relationship between some of the acute phase proteins and an increased $L p(a)$ level. The potential acute phase character of $L p(a)$ was, however, questioned by Slunga et al (112). Increased $L p(a)$ levels have also lately been demonstrated in rheumatological conditions such as Behcets syndrom (113), systemic lupus erythematosus (114) and primary gout (115).

In RA several different pathways can lead to increased formation of oxygen free radicals which may be important for tissue damage in joints (116) and also in processes such as oxidization of LDL (50). Micronutrients act as antioxidants and free radical scavengers. One study recently showed that patients with low levels of alpha-tocopherol, beta-carotene and selenium had an elevated, although not statistically significant, risk of developing RA (24). Another study revealed low levels of selenium and an inverse relationship between the concentration of ascorbic acid and acute phase reactants (23).

\section{OTHER FACTORS}

Elevated levels of anticardiolipin antibodies ( $\mathrm{aCL}$ ) have been correlated with tromboembolic complications of both veins and arteries in cerebrovascular incidents, MI and deep vein thrombosis, besides habitual idiopathic abortion. For recent review, see Cervera et al (117). It is well known that patients with antiphospholipid syndrome (APS) and some patients with systemic lupus erythematosus (SLE) have pathological titers of aCL. Anticardiolipin antibodies have been found in several other conditions and in normal populations, but in these cases there is usually no association with any features of APS (117). However, in a recent study the rate of thrombotic events was higher in RA than in controls. The levels of $L p(a)$ were significantly higher in aCL-positive women with RA than in aCL-negative patients as well as controls, suggesting a further thrombogenic factor in these patients (118). 
Lazarevic (119) found antibodies to VLDL and LDL in $38 \%$ of patients with RA compared to none in controls. Thus, the dyslipoproteinemia in RA was suggested to have an autoimmune pathogenesis.

\section{PHARMACOLOGICAL TREATMENT.}

There are numerous, often contradictory, reports on the impact of corticosteroid treatment on the lipid profile as well as on haemostasis. The most commonly reported alteration of lipids is an increase of cholesterol in various lipoproteins (120) whereas the effect on the components of the fibrinolytic system seems complex and the net effect difficult to anticipate (121-123). In a recent review Maxwell et al (120) finds support for an association between regular systemic corticosteroid treatment and increased CVD. Possible underlying mechanisms for vascular damage, such as hypertension, insulin resistence, lipid profile, obesity and haemostasis, were discussed. According to one study (124), RA patients treated with corticosteroids had more frequent and more extensive arteriosclerosis than nontreated patients. On the other hand, Rasker \& Cosh (125) found no association between steroid treatment and CVD death in RA patients. This was further supported in a recent study by Raynauld et al (126). Monson \& Hall (1976) demonstrated increased CVD death already prior to the introduction of corticosteroid treatment, indicating that other factors are of importance for CVD progress in RA. The situation differs from that of SLE, another inflammatory systemic disease, in which the connection between CVD and corticosteroid treatment is more generally accepted (129).

Most RA patients are treated with acetylsalicylate (ASA) or NSAID. Whereas some authors have suggested that antiphlogistics in RA protect against CVD (45) others have found increasing death rates, generally and for CVD but not for IHD, with increasing frequency of aspirin intake (29). When RA patients were compared to osteoarthrosis patients with similar aspirin consumption eight times higher excess mortality was found in RA (29). They concluded, that factors other than asprin usage were much more important for the excessive death rate in RA. Acetylsalicylate exerts an antithrombotic effect by inhibiting the enzyme cyclooxygenase, and concomitantly the thromboxan production, in platelets. ASA in doses of $75-325 \mathrm{mg} /$ day has been shown to reduce the incidence of $\mathrm{MI}$ and stroke in patients with high risk of occlusive vascular disease (130). Doses upto $1000 \mathrm{mg} /$ day, i.e. doses which are more adequate from the rheumatologic point of view, did not change the protective effect significantly (130).

Contrary to the effect of treatment with other DMARD (gold, penicillamine, azathioprine, cyclophosphamide and corticosteroids), treatment with antimalaria 
drugs was shown to further lower the already reduced total lipid and lipoprotein levels in active RA (131). Chloroquine is a lysosomotropic drug which has several antiatherothrombotic effects, (132) one of which is suppression of VLDL secretion from cultured hepatocytes (133). It has also been shown to inhibit the T-cell stimulatory effect of oxidized LDL (134).

Treatment with penicillamine, a chelate binder which binds to macromolecules, has been suggested to cause increase in lipid levels via copper depletion (135). On the other hand penicillamine could inhibit platelet dependent coronary artery thrombosis in dogs (136).

Estrogens in doses used for hormone replacement therapy (HRT) are increasingly prescribed to RA patients for prevention of osteoporosis. On the basis of former studies on men (137), high doses of estrogens have been regarded to increase the risk of CVD. In contrast to this, a metaanlysis on mainly healthy women (138) showed that the risk of coronary heart disease in women treated with estrogen postmenopausally was reduced by about $50 \%$. This may be explained by a favourable, non-dose related, effect on the fibrinolysis together with a dose dependent - and thus small - impact on coagulation in the low-dose range of hormone replacement therapy (139). Alternatively, decreased LDL level, increased HDL level and a marked repression of the $L p(a)$ level may account for the reduced risk (140). 


\section{OBJECTIVES}

With the background outlined above the aims of the present study on patients with RA were

* to study the epidemiology of CVD in RA in the county of Västerbotten and the influence of some traditional risk factors and of some factors associated to RA per se and to its treatment on mortality and CVD morbidity.

* to evaluate the relationship between levels of lipids and $\mathrm{Lp}(\mathrm{a})$ and inflammatory activity.

* to investigate the lipid metabolism, as measured by LPL activity and mass, in relation to inflammatory variables, and by triglyceride clearence in a fat tolerance test.

* to relate endothelially-produced haemostatic factors, vWF, PAI-1 and tPA, besides fibrinogen and platelet count, to systemic extraarticular disease and to progression of CVD at a follow-up.

* to evaluate the significance of an altered fibrinolysis in the destruction of the joint, the target tissue of the rheumatoid inflammation. 
The distribution of the patients in papers I-III and V are presented in Fig 3. Number of patients and gender distribution of all patients and controls, their mean age and mean disease duration, are presented in Table II.

\section{PAPER I}

All patients registered during 1979 at the Department of Rheumatology, University hospital, Umeå, with the diagnosis seropositive RA, classification number 712,38 according to the Nordic modification of the international classification of diseases (ICD 8, Swedish National Board of Health and Welfare 1968) (141), were included in this epidemiologic survey. A total of 630 patients were included, counting in- and out-patients as well as consultation patients. Twenty-four patients were excluded because of incorrect registration (4), wrong diagnosis (18) or because they could not be identified (2). The final sample comprised 606 patients (412 female, 194 male). All patients fulfilled the 1957 criteria of definite RA (142) and the 1987 revised criteria for RA (143).

Information on the underlying cause of death for the deceased was obtained from the National Central Bureau of Statistics (SCB). To achieve comparable data, death certificates prior to 1987 were recoded by the SCB according to ICD 9 (144), which was applicable from 1987. The population and the cause of death statistics of the county of Västerbotten for 1987 were used as reference in the mortality study.

All patients records were thoroughly read and followed to the end of 1994 or up to the death of the patient. The following variables were registered to analyse predictors for CVD and death: gender, age at disease onset, oral corticosteroid treatment ( $\geq 12$ months), treatment with disease modifying drugs (DMARD, $\geq 6$ months for each drug), hypertension (treatment $\geq 12$ months), diabetes mellitus, hormone replacement therapy (HRT, i.e. estradiol, estriol and dienoestrol $\geq 6$ months), HLA typing (A, B and DR antigens, $n=115$ ) and cardiovascular event. Events were subgrouped in four categories: deep vein thrombosis/pulmonary embolism, myocardial infarction, cerebrovascular lesion/transient ishemic attack and other events.

\section{PAPERS II, III AND V}

Ninety-three in-patients (75 female, 18 male) were originally enrolled consecutivelly for the study on $\mathrm{Lp}$ (a) in RA (Paper II). All patients fulfilled the criteria for classical seropositive RA (142) and had median disease activity according to the Cooperating Clinics Committee of the American Rheumatism 
Association (145). All patients were free from clinical and laboratory signs of diabetes mellitus, infections, kidney-, liver- and thyroid diseases or malignancies. Controls were 67 mean age-matched healthy subjects (33 female, 34 male), who were sampled in a health project from the same county as the patients.

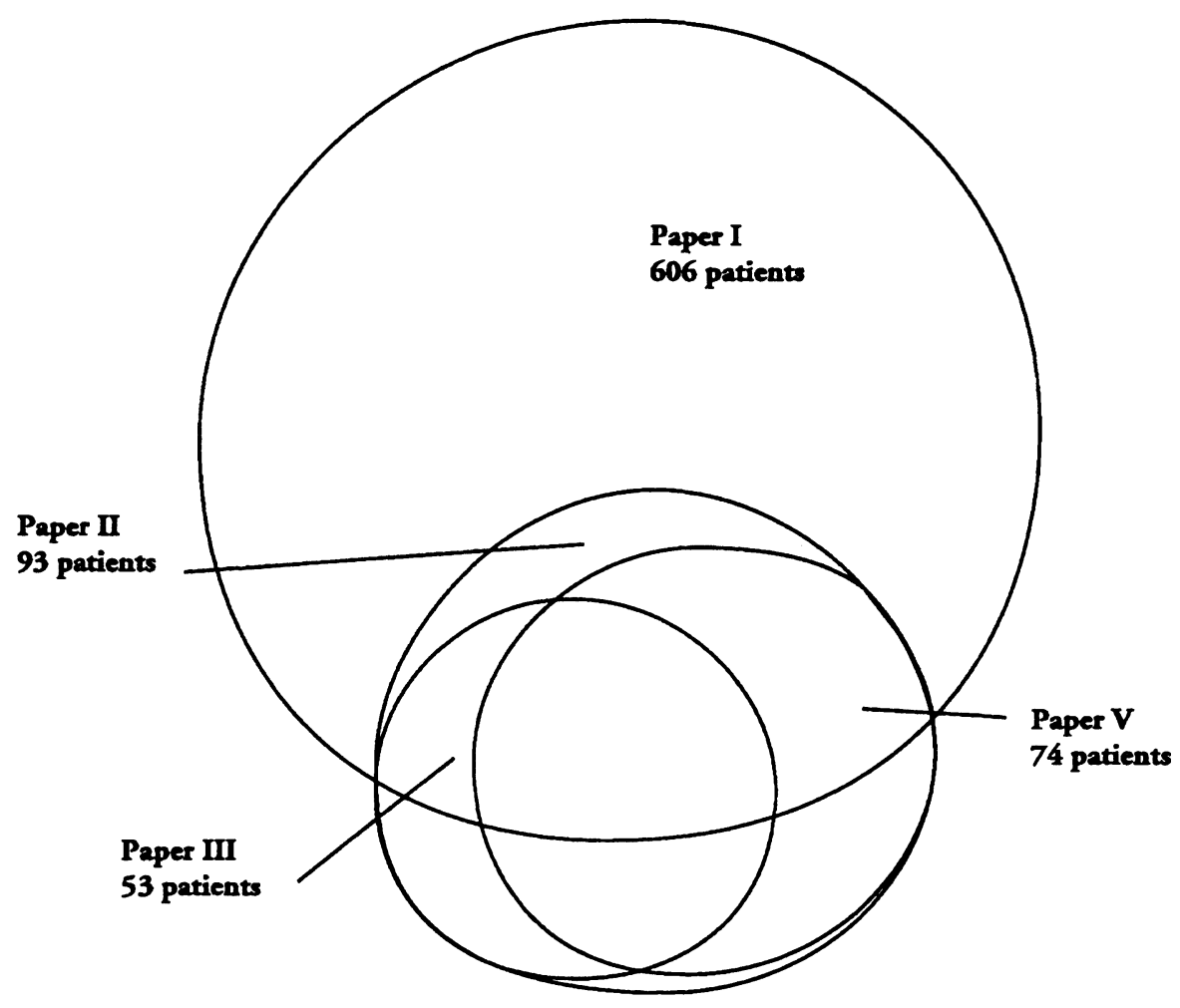

Fig 3. Distribution of patients in studies I-III and V.

Seventy-four out of the originally enrolled 93 patients were examined again for a study on endothelially-produced haemostatic factors in RA (Paper V). Of these, 61 were females and 13 were males. The drop out was due to death $(n=4)$, refusal to take part $(n=9)$, development of diabetes mellitus $(n=3)$ or due to the fact that the patients had moved to another reference area $(n=3)$. Different groups of patients were compared with regard to endotheliallyproduced haemostatic factors: patients with extra articular disease $(n=12)$ compared to those without $(n=64)$, and patients with thromboembolic events in a two year follow-up $(n=8)$ compared to those without $(n=66)$. 
Fifty-three of the original 93 patients ( 47 female, 6 male) were included in a follow-up study, 5.5 years after the initial sampling, on $L p(a)$ in relation to acute phase proteins (Paper III). Twenty-eight patients had deceased, three had developed diabetes mellitus, three had moved to other reference areas and four to peripheral nursing homes. Two cases were dropped due to laboratory faults.

\section{PAPER IV}

Seventeen consecutive postmenopausal women with inflammatory active RA (143) were included in this study on the role of LPL in RA. Sixteen postmenopausal women from the same area were used as controls. Patients as well as controls were selected according to the following criteria: they were free from diabetes mellitus, renal disease, former cerebral and myocardial infarction, thrombosis and known familiar hyperlipidemia, and they were nonsmokers and not treated with oral corticosteroids or HRT, except for estriol.

In addition 15 of the patients and 15 of the controls took part in an oral fat tolerance test to investigate the triglyceride clearence. One individual from each group were excluded since they could not tolerate the fat meal.

\section{PAPER VI}

A consecutive series of 29 patients ( 21 female, 8 male) fulfilling the criteria for RA (143) were included in this study on fibrinolytic components in synovial fluid and their relation to joint destruction as measured radiologically. Their mean ESR was $48 \mathrm{~mm} / \mathrm{h}$ (range 16-105) and the mean ( \pm SEM) synovial fluid leucocyte particle concentration (LPK) was $9.2( \pm 0.7) \times 10^{9}$. Eighteen consecutive patients ( 9 female, 9 male) with spondylarthropathy (SpA, ESSG criteria) (146) were also enrolled; patients with psoriatic arthritis were not included. The mean ESR was $37 \mathrm{~mm} / \mathrm{h}$ (range 2-90) and mean ( \pm SEM) synovial fluid LPK was $9.4( \pm 2.0) \times 10^{9} / 1$. Controls were ten subjects $(7 \mathrm{male}$, 3 female) who had been referred to arthroscopy because of noninflammatory conditions. Their mean ( \pm SEM) synovial fluid LPK was $0.05( \pm 0.03) \times 10^{9} / 1$. 
Table II. Demographic data on patients and controls in all studies

\begin{tabular}{|c|c|c|c|c|}
\hline \multicolumn{2}{|c|}{ Paper } & \multirow{2}{*}{$\begin{array}{l}\mathrm{N}(\mathrm{f} / \mathrm{m}) \\
606(412 / 194)\end{array}$} & \multirow{2}{*}{$\begin{array}{l}\text { Mean age, years } \\
\text { (range) }\end{array}$} & \multirow{2}{*}{$\begin{array}{l}\begin{array}{l}\text { Mean disease } \\
\text { duration (range) }\end{array} \\
12.5(0-61) \dagger \\
13.5(0-51) \dagger \dagger\end{array}$} \\
\hline $\bar{I}$ & $\mathrm{RA}$ & & & \\
\hline II & $\begin{array}{l}\text { RA } \\
\text { Controls }\end{array}$ & $\begin{array}{l}93(75 / 18) \\
67(33 / 34)\end{array}$ & $\begin{array}{l}62.8(25-80) \\
60.0\end{array}$ & $20.9(0.5-51)$ \\
\hline III & $\mathrm{RA}$ & $53(47 / 6)$ & $58.3(25-78)^{*}$ & $19.0(1-49)$ \\
\hline IV & $\begin{array}{l}\text { RA } \\
\text { Controls }\end{array}$ & $\begin{array}{l}17(17 /-) \\
16(16 /-)\end{array}$ & $\begin{array}{l}63.1(52-79) \\
65.4(56-72)\end{array}$ & $22.4(2-48)$ \\
\hline V & RA & $74(61 / 13)$ & $63.5(27-82)$ & $21.9(1.5-52)$ \\
\hline VI & $\begin{array}{l}\text { RA } \\
\text { SpA } \\
\text { Controls }\end{array}$ & $\begin{array}{l}29(21 / 8) \\
18(9 / 9) \\
10(3 / 7)\end{array}$ & $\begin{array}{l}56.2(39-75) \\
45.3(18-75) \\
34.9(25-54)\end{array}$ & $\begin{array}{l}15.5(1-57) \\
10.1(1-35) \\
-\end{array}$ \\
\hline
\end{tabular}

$\uparrow$ females $\dagger \dagger$ males $*$ Mean age at the first sampling $\mathrm{SpA}=$ seronegative spondylarthropathy

\section{METHODS}

\section{LABORATORY PROCEDURES}

Lipids, lipoproteins and apolipoproteins (papers II-V)

Cholesterol, triglycerides (papers II-V) and cholesterol in HDL (Paper V) were determined enzymatically with reagent kits (Boehringer, Mannheim, Germany). LDL (paper V) was calculated according to Friedewald (147).

$\mathrm{Lp}$ (a) in study II was analysed with a radioimmunoassay (RIA) kit ( Pharmacia Diagnostics, Uppsala, Sweden). In study III, an enzyme-linked immunosorbent assay (ELISA) was used. The detection limit was $10 \mathrm{mg} / \mathrm{l}$, the assay range 10$600 \mathrm{mg} / \mathrm{l}$. Plasminogen did not interfere with the assay. In study V, ELISA (Tint ELIZE ${ }^{\mathrm{TM}}$, purchased from Biopool, Umeå, Sweden), was used for the $\mathrm{Lp}(\mathrm{a})$ analysis.

Apolipoproteins A-I and B (paper II) were analysed with RIA research kits (Pharmacia diagnostics, Uppsala Sweden). 
Lipoprotein lipase (Paper IV)

LPL activity was measured at $25^{\circ} \mathrm{C}, \mathrm{pH} 8.5$ using Intralipid ${ }^{\circledast}$ into which $3 \mathrm{H}-$ labelled triolein had been added by sonication (148). LPL mass was determined by ELISA (149).

\section{Fibrinolytic components (papers V-VI)}

In paper V, plasma IPA activity was measured with a parabolic rate assay, based on fibrin stimulation of the tPA mediated conversion of plasminogen to plasmin (150) (Spectrolyse/fibrin ${ }^{\mathrm{TM}}$, Biopool, Umeå, Sweden). Tissue plasminogen activator capacity was defined as the difference between the activity before and after the venous occlusion test. PAI-1 activity was analysed with an assay based on polylysine stimulated plasminogen conversion to plasmin (151) using kits from Biopool (Spectrolyse/Pl ${ }^{\mathrm{TM}}$ ).

In paper VI, synovial fluid was centrifuged at $2000 \mathrm{~g}$ for 20 minutes before freezing. The same methods were used when analysing plasma and synovial fluid. Activities of tPA and PAI-1 were analysed by biofunctional immunosorbent assay methods (BIA, Chromolize $\mathrm{tPA}^{\mathrm{TM}}$ and Biopool, respectively). Strong acidic sodium citrate anticoagulant $\left(\mathrm{pH} 4.3\right.$, Stabilyte $\left.{ }^{\mathrm{TM}}\right)$ (152) was used when collecting plasma and synovial fluid for analysis of tPA activity to prevent tPA-PAI complex formation. Pro-urokinase (pro-uPA) activity was also determined with BIA (Chromolize $\mathrm{uPA}^{\mathrm{TM}}$, Biopool), as described by Rånby et al (153). Plasminogen was determined by a tPA/fibrin activation method (Spectrolyse Plasminogen ${ }^{\mathrm{TM}}$, Biopool). Fibrin degradation product D-dimer, PAI-1 antigen and plasminogen activator inhibitor-2 (PAI-2) antigen were determined by commercialized ELISA methods (Tint ELIZE Ddimer $^{\mathrm{TM}}$, Tint-ELIZE PAI-1 ${ }^{\mathrm{TM}}$ and Tint ELIZE PAI-2 ${ }^{\mathrm{TM}}$, respectively, Biopool). Antibody blanking was in all cases used as a test of specificity of the ELISA (154).

von Willebrand factor (paper V)

An ELISA (155) with antibodies and conjugate purchased from DAKO (Gentofte, Denmark) was used for measuring vWF.

\section{Inflammatory variables (papers II-V)}

Haptoglobin, orosomucoid and CRP were measured by immunoturbidimetry using antisera from Beckman, USA. Fibrinogen (paper V) was determined using a fibrometer with a thrombin reaction rate assay (Bio Merieux, Charbonnaireles-Baines, France) and, as fibrinogen mass, with immunoturbidimetry (paper IV). Platelets (paper V) were counted in a Coulter S plus cell counter. Erythrocyte sedimentaton rate (ESR, Westergren method) was measured routinely. The leucocytes in synovial fluids were counted in a Bürker chamber. 
Cytokines (paper IV)

Tumour necrosis factor- $\alpha$ (TNF- $\alpha$ ), interleukin 1- $\beta$ (IL-1B) and interleukin-6 (IL-6) were measured with immunoenzymetric assay kits (Medgenics dignostics SA, Fleurs, Belgium).

\section{RADIOGRAPHY (paper VI)}

Radiograms of the knee joints were examined blindly and graded according to the Larsen grading system (156).

\section{ORAL FAT LOAD (paper IV)}

After an overnight fast, patients and controls ingested a mixture containing soybean oil $\left(50 \mathrm{~g} / \mathrm{m}^{2}\right)$, glucose $\left(50 \mathrm{~g} / \mathrm{m}^{2}\right)$, egg white protein $\left(6.3 \mathrm{~g} / \mathrm{m}^{2}\right)$, dried egg yolk $6.3 \mathrm{~g} / \mathrm{m}^{2}$ ) as described by Karpe et al (157). The total energy content was $60.2 \%$ fat, $13.3 \%$ protein and $26.5 \%$ carbohydrate.

\section{STATISTICS}

Generally, nonparametric tests were used because of scewness and/or small samples for some variables. Differences in continuous data were tested with the Mann Whitney U-test (papers II, IV-VI). However, in cases of comparison between more than two groups, tests of variance were first performed: two way ANOVA (paper II) and the Kruskal-Wallis test (paper VI). In tests of difference between paired data (papers III, IV) the Wilcoxon signed rank test was used.

Correlations between variables were assessed by Pearson's product moment correlation test (paper II) and Spearman's rank correlation test (papers III-VI). The latter allows correlation tests between ordinal and continuous data (paper VI).

In paper $\mathrm{V}$, logistic regression analysis was performed to evaluate the explanatory value of the variables entered in the model, for thrombembolic events. P-values of $<0.05$ were considered to be significant.

In paper I, SMRs were calculated with a direct method (158). Significancies of differences between the study group and the reference population were assessed by means of the Poisson distribution. Survival distributions for total mortality were estimated according to the PL-estimator (159) for the study group and reference population, matched for age and length of follow-up. Equality between observed and expected survival distributions were tested 
according to the Log Rank test (160). The Cox proportional hazards regression model (161) was used to identify important predictor variables relating significantly to the length of survival and to time to first cardiovascular event.

The statistical calculations in paper II were performed by means of StatView (Brain Power Inc, Calabasas, Ca, USA). In papers III-VI, StatView II (Abacus Concepts Inc, Berkeley, Ca, USA) was used. The Cox proportional hazards regression analyses (paper I) were performed with the SPSS package (162).

\section{ETHICAL ASPECTS}

All patients and controls had given their informed concent to take part in the studies. All study protocols have been approved by the local Human Ethics Committee at the University Hospital, Umeå, Sweden.

\section{MAIN RESULTS}

\section{EPIDEMIOLOGY (Paper I)}

The SMR demonstrated a significantly higher total death rate (SMR 1.57, $\mathrm{p}<0.001$ ) in both sexes $(1.64, \mathrm{p}<0.001$ for females; $1.47, \mathrm{p}<0.001$ for males) compared to the population of Västerbotten. The same result was illustrated by significantly decreased survival functions in males and females $(p<0.001$ for both) compared to the reference population (Figs $4 a$ and $b$ ). In both sexes, death rate increased with time in RA. SMR for underlying death causes revealed a significant excess of the death rate for CVD overall (SMR 1.46, $p<0.001$ ) as well as for the subgroup IHD (SMR 1.54, $\mathrm{p}<0.001$ ). The differences were significant in both sexes.

Simple Cox regression analysis, with time from disease onset to death as response variable, revealed significantly increased risk of death for the male sex, high age at disease onset, hypertension and cardiovascular event. Treatment with DMARD and HRT significantly decreased the risk. Corticosteroid therapy, diabetes mellitus and HLA antigens had no effect on the risk of death. 
(a)

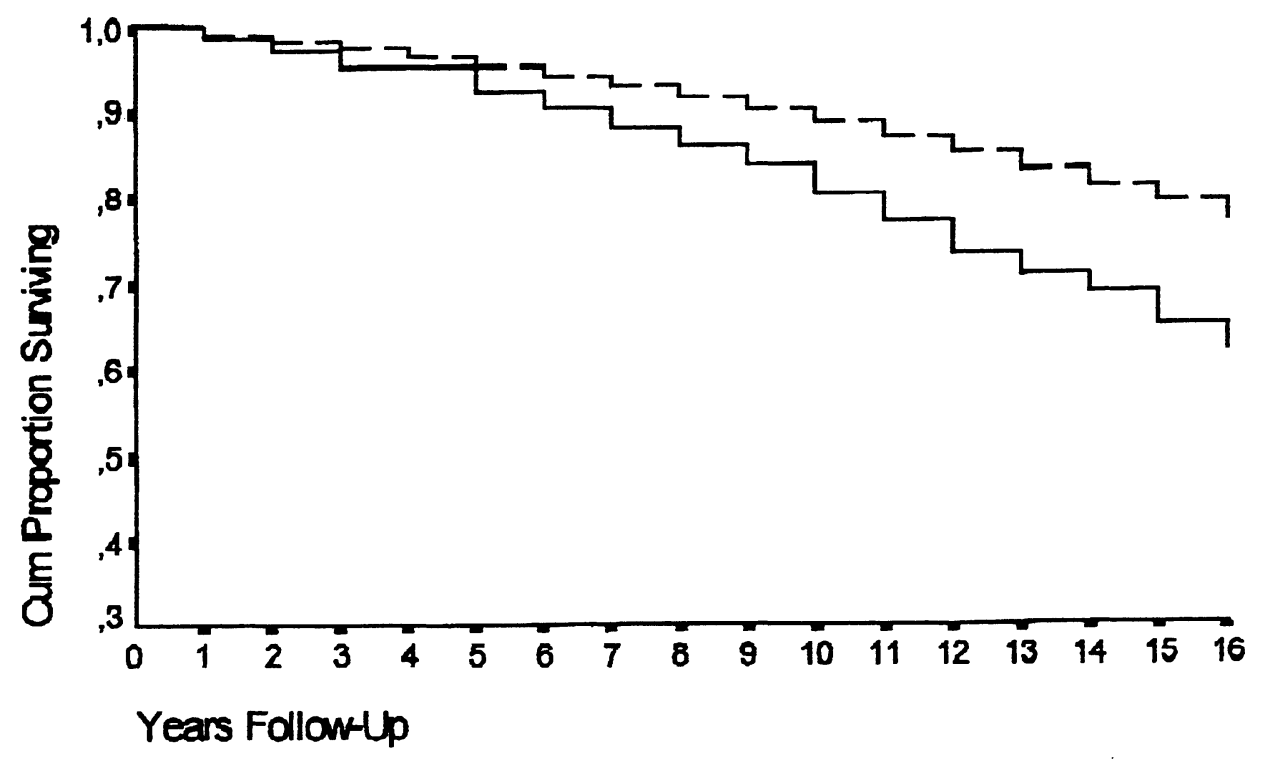

(b)

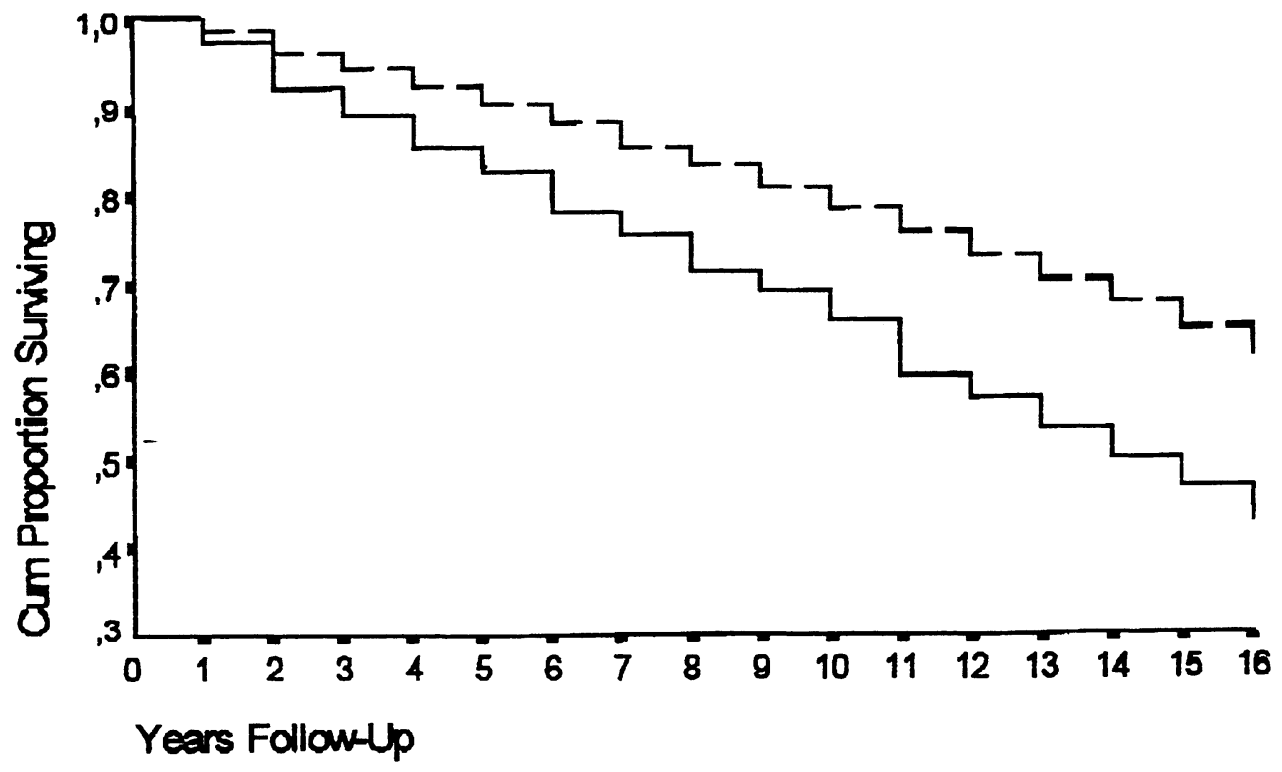

Figures $4 a$ and $b$. Observed and expected survival functions for female (a) and male (b) with RA (unbroken line) and for the population of Västerbotten (broken line). 
In the multiple Cox regression, with time from disease onset to death as response variable, male sex, higher age at disease onset and cardiovascular event were significantly related to increased risk of death. When time from disease onset to first cardiovascular event was defined as response variable, male sex, high age at disease onset and hypertension indicated increased risk of event. Diabetes mellitus, treatment with corticosteroids, DMARD and HRT did not significantly influence any of the response variables in the multiple regression.

\section{ATHEROGENESIS (Papers II-IV)}

\section{Lipids}

The levels of total cholesterol $(p<0.001)$ as well as HDL-cholesterol $(p<0.05$, papers II and IV) and LDL-cholesterol ( $<<0.001$, paper IV) were significantly lower compared to controls. Triglycerides were lower, but without statistical significance, in patients compared to controls (papers II and IV).

\section{$\underline{L p(a)}$}

In patients with $R A$ of median disease activity, $L p(a)$ was significantly elevated $(\mathrm{p}<0.05)$ compared to mean age-matched controls. Treatment with corticosteroids, NSAID and DMARD had no significant influence on $\mathrm{Lp}(\mathrm{a})$. A significant correlation was found between $\operatorname{Lp}(\mathrm{a})$ and inflammatory variables, i.e. orosomucoid $(p<0.05)$, ESR $(p<0.001)$ and platelet count $(p<0.05)$ in patients with $\mathrm{Lp}(\mathrm{a})$ levels exceeding $480 \mathrm{mg} / \mathrm{l}$, corresponding to about $2.5 \%$ of the $L p(a)$ levels found in reference populations (163).

By the time of the second sampling, the level of ESR $(p<0.05)$ and all acute phase proteins - orosomucoid $(p<0.001)$, haptoglobin $(p<0.05)$ and CRP $(p<0.01)$ - had decreased significantly. The $\operatorname{Lp}(\mathrm{a})$ level had increased in $63 \%$ of the RA patients, resulting in a significant increase in $L p(a)$ for the whole group ( $p<0.01)$. The change in $\operatorname{Lp}(a)$ was correlated to the changes of ESR $\left(\mathrm{r}_{\mathrm{s}}=0.59, \mathrm{p}<0.001\right)$ and haptoglobin $\left(\mathrm{r}_{\mathrm{s}}=0.31 \mathrm{p}<0.05\right)$. There was also a significant increase of the triglyceride level $(p<0.05)$ while the cholesterol levels remained unchanged.

The interindividual variations between the samplings were large. In a cluster of patients with initially low $\mathrm{Lp}$ (a) levels $(<172 \mathrm{mg} / \mathrm{l})$, the change was small and insignificant and did not correlate to any of the acute phase reactants or ESR. In patients with high initial $L p(a)$ levels $(>172 \mathrm{mg} / 1)$ the increase of $L p(a)$ was significant and correlated to ESR $\left(r_{s}=0.75, p<0.001\right)$. There were no significant correlations between the changes of the levels of $\operatorname{Lp}(\mathrm{a})$ and the respective lipids, in all patients or in the subgroups. 


\title{
LPL
}

LPL levels, measured as activity and protein mass, were generally lower in RA compared to controls, particularly in preheparin plasma $(p<0.01$ for LPL activity and mass, respectively). The low specific activity (LPL activity/mass) demonstrated that preheparin plasma contained mostly catalytically inactive LPL. Preheparin LPL mass showed significant inverse correlations to orosomucoid and CRP ( $\mathrm{p}<0.05$ for both) with inverse correlations, close to significant, also to haptoglobin and IL-6. An inverse correlation between preheparin LPL activity and haptoglobin $(p<0.05)$ was the only other significant correlation between any LPL variable and inflammatory variables. Unlike the situation in the controls, no LPL variable was correlated to any of the lipids nor to the lipoproteins in RA.

The generally lower LPL levels, particularly the preheparin mass, in RA compared to controls, were verified in the fat tolerance test. The clearence of triglycerides, as measured by the difference between pre- and post fat load levels, showed lower absolute and relative values. These differences were, however, not statistically significant.

\section{HEMOSTATIC FACTORS (Papers V-VI)}

In the circulation

Figures 5 and 6 show the plasma concentrations of the endothelially-produced haemostatic factors in patients with extraarticular disease and patients with thromboembolic events in the follow-up, compared to those without.

\author{
Bild borttagen - se tryckt version \\ Image removed - see printed version
}

Fig 5. Plasma concentrations of PAI-1, tPA and vWF in RA patients with extra articular disease (EA) and in patients without EA. The horizontal bars denote the mean values. 
Patients with extraarticular disease had, compared to patients without, significantly higher PAI-1 activity $(\mathrm{p}<0.05)$ and significantly lower tPA capacity $(p<0.05)$, while neither ESR nor any of the acute phase reactants were significantly different. The vWF did not differ significantly between the groups. Three of the twelve patients with extraarticular disease suffered from thromboembolic events during the two-year follow-up compared to five of the 62 patients without systemic engagement.

Patients who suffered a thromboembolic event during the follow-up had, compared to patients without event, significantly higher vWF and PAI-1 activity ( $<<0.05$ for both) but showed no significant difference for the tPA capacity. They also had significantly higher levels of haptoglobin and triglycerides $(p<0.05$, both variables). Notably, neither the levels of fibrinogen nor platelets differed significantly between the groups. When entered in a logistic regression model, vWF was the haemostatic variable that was the strongest predictor of thromboembolic events.

$$
\begin{aligned}
& \text { Bild borttagen - se tryckt version } \\
& \text { Image removed - see printed version }
\end{aligned}
$$

Fig 6. Plasma concentrations of PAI-1, tPA and vWF in RA patients who suffered from thromboembolic events (TE) during a two-year follow-up and in patients without TE. The horizontal bars denote the mean values. 
In the joint

In the comparison between $\mathrm{RA}$ and $\mathrm{SpA}$, synovial fluid of patients with $\mathrm{RA}$ showed significantly higher levels of PAI-1 antigen $(p<0.001)$ and PAI-1 activity $(\mathrm{p}<0.05)$ and a tendency towards lower tPA activity $(\mathrm{p}=0.061)$.

RA plasma showed significantly higher levels of $D$-dimer $(p=0.0001)$ and PAI-1 antigen $(p=0.0001)$ and a tendency towards lower tPA activity $(p=0.054)$.

An inverse correlation, close to significant, between synovial fluid plasminogen and joint destruction, as measured radiologically and graded according to Larsen (156), was found in RA patients $\left(r_{s}=-0.37, p=0.054\right) . P$ atients with $R A$ revealed a higher Larsen grade than patients with $\mathrm{SpA}$, but the difference was not significant. With all patients pooled together, synovial fluid plasminogen showed a significant inverse correlation $\left(r_{s}=-0.29, p<0.05\right)$ and PAI-1 antigen showed a significant positive correlation $\left(r_{s}=0.30, p<0.05\right)$ to the radiologic destruction.

Plasma PAI-2 antigen showed an inverse correlation to Larsen grade $\left(r_{s}=-0.34\right.$, $\mathrm{p}<0.05$ ) in all patients.

\section{DISCUSSION}

\section{EPIDEMIOLOGY}

The epidemiologic study comprises a cohort large enough to expose significant differences in the underlying causes of death and to identify predictors for CVD and death. All tested predictor variables were either established risk factors or selected to have a potential impact on CVD or death. The study is, however, retrospective, which means that information in the records had to be relied upon to large extent. Thus, information on smoking, an established cardiovascular risk factor, was defective and therefore not registered. Furthermore, the major part of the population was not followed from the disease onset which means that markers for disease activity are lacking.

The study verified the increase of the overall death rate previously reported in several studies on patients with RA $(26-42,44)$. In line with other reports, death was predicted by high age at disease onset and male sex $(31,42,164)$ and cardiovascular event (165). The increasing death rate over time may implicate a cumulative effect of the disease intensity, other factors associated to the disease and to comorbidities. Mortality due to CVD was high in line with other reports $(28,29,32,34,39,42,44)$ and we found age at disease onset, male sex, and hypertension to be predictors of cardiovascular event. Although previous 
reports have been contradicting, an excess death rate due to IHD was clearly demonstrated in this study. On the contrary, death due to cerebrovascular disease did not differ from the reference population.

A relationship between corticosteroid treatment and increased death (166) and CVD $(120,124)$ in RA has been claimed. However, in line with several other reports on steroid consumption and CVD $(29,125,126)$, we found no predictive effect of corticosteroids on either CVD or death. It is conceivable, that the negative side effects of corticisteroids on survival and CVD progression are balanced by the benefit of a reduced disease activity in RA. A net beneficial effect of corticosteroids on osteoporosis ( $>5 \mathrm{mg} /$ day) (127), as well as on joint destruction $(7.5 \mathrm{mg} /$ day) $(128)$ has recently been reported.

The fact that DMARD treatment significantly decreased the risk of death in simple regression may also be an expression of a beneficial effect of decreased inflammation in RA on survival. A positive effect of gold treatment on general survival in RA has previously been reported (167). Furtermore, an appreciable decline in the number of deaths due to amyloidosis in patients with juvenile rheumatoid arthritis was regarded to be due to increased use of cytotoxic drugs (168).

To conclude, except for the significant relationship between hypertension and cardiovascular event, neither the registered established risk factors nor corticosteroid treatment did crystallize as predictors for CVD or death in RA. However, as outlined above, several other physiological processes involved in atherogenesis and haemostasis are known to be influenced in inflammatory active rheumatoid artritis.

\section{ATHEROGENESIS IN RA}

\section{Lipids and Lp(a)}

The low levels of total- and LDL cholesterol in active RA show a nonatherogenic pattern. In line with this concept, lower levels of triglycerides were found in active RA compared to controls but this difference was not statistically significant. However, evidence against this concept was provided by the finding of simultaneous decrease of the HDL-cholesterol level, the atheroprotective effect of which has been documented (102). Our findings are consistent with those of several other authors (15-17). The increasing triglyceride level with decreasing disease activity found in study III further underlines the association between inflammation and lipid levels which has formerly been discussed (169). 
$\mathrm{Lp}(\mathrm{a})$ is an LDL-like lipoprotein with a specific antigen, apo(a), attached to apo B 100 , by a disulphide bridge. The physiological role of $L p(a)$ is unknown but it has been suggested to play a role in the wound haeling process (170). It has been shown to predict MI (107), coronary artery disease (106) and stroke (171). It is possibly in vivo, as described in vitro (172), taken up in aggregated form by macrophages via the scavenger receptor. In a recent study on mice double transgenic for apo(a) and apo(B), strong atherogenesis was demonstrated, suggesting a causal role for $L p(a)$ in atherogenesis (173). Furthermore, the structure of apo(a) is very similar to the structure of plasminogen, the precursor of plasmin, which is the main proteolytic enzyme of fibrin. It has thus been proposed to be a link between atherogenesis and thrombogenesis. $\mathrm{Lp}$ (a) has no proteolytic capacity per se (174) but studies in vitro have shown, that in concentrations known to be dangerous for CVD, $\mathrm{Lp}(\mathrm{a})$ is able to competitively prevent binding of plasminogen and tPA to the fibrin of a thrombosis competitively, thus inhibiting plasmin activation and fibrinolysis $(108,109)$.

The $L p(a)$ level was significantly elevated in patients with active RA compared to meanage-matched controls. Our findings were supported in a recent study on 78 female patients with seropositive RA (118). In our patients with high concentrations $(>480 \mathrm{mg} / \mathrm{l}), \mathrm{Lp}(\mathrm{a})$ showed a significant correlation with several acute phase reactants which is in line with the suggestion of $\mathrm{Lp}(\mathrm{a})$ having an acute phase character $(110,111)$, a concept that has been questioned (112).

In the follow up study on 53 of the original 93 patients, the disease activity, as measured by the acute phase reaction, had decreased significantly. Despite this, no consistent acute phase pattern for the reaction of $L p(a)$ was distinguishable. These results are in accordance with those reported by Slunga et al (112).

Two groups of patients were distinguishable. One group with low initial $L p(a)$ levels showed small changes without any correlation at all to the variation of the acute phase reactants. The other group, with initially high levels of $L p(a)$ showed a significant increase of the $L p(a)$ level, significantly correlated to the change of ESR but not to the changes of the other acute phase reactants. This is in line with the results from the initial sampling, where only the patients with the highest levels of $\mathrm{Lp}(\mathrm{a})$ showed some correlation to acute phase proteins.

Intraindividual variations seem to be restricted to a subgroup of RA patients with the capacity to produce high levels of $\mathrm{Lp}(\mathrm{a})$. In this group, the only evidence of any influence of the acute phase reaction on the $L p(a)$ level is apparent in its correlation with ESR. It is possible that factors such as altered synthesis and metabolism of lipoproteins, and even antibodies to lipoproteins (119) may conceal an acute phase pattern of $\operatorname{Lp}(a)$ in active rheumatoid 
inflammation. Considering the fact that IL-6 regulates the transcription of many acute phase reactants, it is of interest that multiple IL- 6 responsive element consensus sequencies have been demonstrated in the apo(a) gene promotor (175). This could explain any contribution of inflammatory status to the $L p(a)$ level.

The intraindividual $L p(a)$ level has been thought to remain stable throughout life and be independent of sex, age and life style factors (176). In recent studies, however, a slight increase in $\mathrm{Lp}$ (a) levels with age, particularly in women, has been demonstrated $(111,112,177)$. The level of $\mathrm{Lp}(\mathrm{a})$ is mainly genetically determined (178). Eighty-five percent of the $L p(a)$ level is heriditable and as much as $90 \%$ of the variability is attributed to the $L p(a)$ gene (178). The lipoprotein shows a considerable interindividual variation, due to a several alleles at the apo(a) locus (179) coding for different size isoforms of $L p(a)$. The $L p(a)$ level is inversely correlated to the size of the apo(a) protein (178). An association to a certain phenotype in RA could thus be one explanation for the individual reactions.

\section{LPL}

We generally found low levels of LPL activity as well as LPL mass, particularly in the base line levels, i.e. before heparin. This is in line with results presented in one former report on LPL in RA (17). However, the studies were not quite comparable, since that study was based on tissue biopsies. The most interesting finding in our study was the total lack of correlation between LPL variables and levels of lipids and lipoproteins, but an inverse correlation between the preheparin mass and several acute phase reactants. The association between inflammation and lipid metabolism is emphasized by the inverse relationship, close to statistical significance, between the preheparin LPL mass level and IL6 , the main cytokine in driving the acute phase reaction.

Besides its function as a triglyceride hydrolyzing enzyme, LPL seems to act as a ligand in binding lipoproteins to cell surfaces $(180)$ and receptors $(181,182)$. It may play a role in the pathogenesis of atherosclerosis by facilitating the formation of foam cells $(183,184)$. LPL activity in postheparin plasma is regarded to reflect the endothelially-bound dimeric, enzymatically functional LPL fraction (185). The LPL protein mass in preheparin plasma seems to reflect mainly the catalytically inactive monomers bound to lipoproteins (149). Only dimers can mediate the binding of lipoproteins to LRP, a receptor which is expressed on hepatocytes (181), on macrophages and smooth muscle cells (182). However, monomers can obviously compete with the dimers for the receptors and recently an inverse correlation was demonstrated between LPL monomer concentration and triglyceride uptake in hepatoma cells (186). Thus, decreased levels of LPL mass, as in RA with active disease, may entail less 
competition for LRP and hence an increased hepatic clearence of lipoproteins. On the other hand, increased LRP-mediated lipoprotein uptake in smooth muscle cells and macrophages would increase the formation of foam cells and plaques.The finding that the triglyceride concentration in the oral fat tolerance test increased less, though not statistically significant, than in the controls further support the concept of enhanced lipoprotein clearence in active RA.

Although these results probably reflect different phases of the triglyceride metabolism they are compatible with other reports on an increased triglyceride clearence in intravenous fat tolerance tests in active RA $(16,17)$. Possibly, an enhanced atherogenesis due to uptake of partly degraded lipoproteins via macrophage scavenger receptors, as suggested by Svenson et al in RA (17), is accentuated by lipoprotein uptake via LRP on macrophages and smooth muscle cells. It can also be hypothesized, that an increased oxidation of LDL in a situation of oxidative stress, i.e. the inflammation in RA, with concomitant radical production from activated macrophages (187), may enhance lipoprotein uptake via scavenger receptors.

\section{HAEMOSTASIS IN RA}

In patients with extraarticular disease none of the acute phase reactants, fibrinogen, platelets or ESR showed any significant difference compared to the patients without apparent systemic engagement. Discrepancies were only found among the haemostatic factors.

Elevated vWF levels have formerly been reported in different vasculitis disorders $(88,89)$ including RA vasculitis $(90-93)$. Our patients with extraarticular disease had slightly higher levels, compared to patients without extraarticular engagement, but the difference was not statistically significant. The PAI-1 activity was significantly elevated and PA release was significantly decreased. Thus, PAI-1 seems to be a better marker for systemic engagement in RA than any of the traditional markers of disease activity, with which PAI-1 moreover did not show any correlation. Since tPA and PAI-1 are produced by the endothelium, this may reflect a feature of vasculitis in these patients. A decreased tPA release together with an increase of the PAI-1 activity may very well implicate a reduced fibrinolytic activity in extraarticular disease. This is supported by the fact, that three of the twelve patients (25\%) with systemic disease suffered from thromboembolic events compared to five of the $62(8 \%)$ without systemic engagement.

Neither fibrinogen nor platelets, both of which are associated with CVD in the general population $(80,83)$, showed any significant association to 
thromboembolic events in RA. However, patients suffering from thromboembolic events during the follow-up revealed significantly elevated levels of vWF, PAI-1 activity, triglycerides and haptoglobin compared to event free patients. The significant increase of haptoglobin suggests that there is a relationship between disease activity and CVD. Neither haptoglobin nor any of the acute phase reactants were significantly increased in the systemic group compared to those without systemic disease. This may point to a more general influence of inflammation on the endothelium than merely in patients with apparent vasculitis.

Rheumatoid vasculitis has been regarded as a rare disease. It appears that a widespread subclinical vasculitis is much more common than formerly considered $(13,14)$ and may have broader clinical implications than are usually appreciated. Systemic production of cytokines, TNF- $\alpha$, IL-1 and IL-6 may, in addition to inducing the acute phase response, affect endothelial cell function and in the long term cause vascular inflammation (12). This has been suggested to be a major determinant of the increased CVD and mortality in RA (12). It could be hypothesized, that a general increase in cytokines of joint origin in RA, reflected by the elevated haptoglobin level in our patients, causes a general increase of expression of adhesion molecules on the endothelial cells with concomitant leucocyte penetration. Even if this is an unspecific process, more leucocytes may be accessible for presentation of antigen (e.g. oxidized LDL) and recognition of macrophage-antigen complexes with concomitant facilitation of an immunological reaction and plaque formation.

In synovial fluid, RA showed significantly higher levels of PAI-1, both as activity and antigen compared to $\mathrm{SpA}$, a disease group of less destructive character. Activities of tPA, pro-uPA and plasminogen were lower, although not significantly, in RA. In the delimited joint compartment, these results may indicate consumption of plasminogen activators and plasminogen and increased complex building between plasminogen activators and PAI-1. This may be an expression of intensified activation of plasmin and other proteolytic enzymes with concomitant fibrinolysis, which are all features of synovitis.

When relating the synovial fibrinolysis to radiological joint destruction, as measured by the Larsen grade (156), an inverse correlation between plasminogen and Larsen grade, close to being significant, was found in the RA group. Although revealing a higher degree of destruction, the RA group did not differ significantly from the SpA group. With all patients pooled together, PAI-1 antigen showed a positive correlation to radiological destruction, and the plasminogen level decreased with increasing Larsen grade. This may be another indication of an enhanced fibrinolysis with plasminogen consumption and concomitant activation of plasmin and other proteolytic enzymes in synovitis. 
This activation of enzymes is apparently associated with joint destruction.

Coagulation and fibrinolysis are induced by the synovitis. An enhanced fibrinolysis may be of benefit for fibrin degradation and clinical status in the short term, as has been proposed $(96,188)$. The same mechanism may, however, be destructive if, in intensive synovitis, the plasmin inhibiting activity is exhausted and activated proteolytic enzymes are free to degrade articular cartilage and joint matrix (2).

The fibrinolytic components in the circulation were not associated with radiological progression, except for an inverse correlation between Larsen grade and PAI-2 antigen. Fibrin split product D-dimer was, however, significantly elevated in plasma of $\mathrm{RA}$ and $\mathrm{SpA}$ compared to controls and significantly higher in RA than in SpA. This may implicate an enhanced intravasal fibrin generation and may be another sign of the altered plasma fibrinolysis formerly reported in RA (188).

\section{CONCLUSION AND FINAL REMARKS}

The studies of this thesis were undertaken based on the background of the reported increased death rate in general, and in CVD in particular, in patients with RA. The aim was to investigate some pathophysiological pathways in lipid metabolism and haemostasis which may be altered due to the inflammatory status in RA. The following can be concluded from the study:

* The overall mortality is in patients with RA higher than in the population of Västerbotten. A higher death rate is, in both sexes, evident also in CVD and in IHD. The total death rate increases over time. In Cox multiple regression analysis, male sex, higher age at disease onset and former cardiovascular event increase the risk of death. Male sex, high age at disease onset and hypertension increase the risk of cadiovascular event. Diabetes mellitus, corticosteroid treatment and HRT neither influence the risk of CVD nor death. In a simple regression analysis DMARD treatment decreases the risk of death.

* Patients with active inflammatory RA have low levels of total cholesterol, HDL- and LDL-cholesterol. The triglyceride level increases with decreasing disease activity. The level of $L p(a)$ is significantly elevated in active RA but has no apparent acute phase character. Any influence of the inflammatory activity on the $L p(a)$ level seems to be restricted to patients who have the capacity to produce high levels of $L p(a)$. 
* LPL, measured as activity and mass in preheparin plasma of patients with active RA are generally low. Preheparin LPL mass, corresponding mainly to the catalytically inactive LPL monomers, shows an inverse relationship to several acute phase reactants and - close to statistically significant - to IL-6, which is the main cytokine responsible for the acute phase reaction. A reduced competition by LPL monomers for LRP may implicate a more efficient hepatic clearence of atherogenic lipoproteins but also a facilitation of foam cell formation. Although not significantly different from controls, a less prominent triglyceride increase in the oral fat tolerance test suggests an increased clearence of lipoproteins in active RA.

* Changes in levels of endothelially-produced haemostatic factors in plasma as well as in synovial fluids are found in patients with active RA. Patients with extraarticular disease show an increase in plasma PAI-1 and a decrease in IPA release, respectively, but no significant change in the traditional acute phase reactants. The levels of $\mathrm{vWF}, \mathrm{PAI}-1$, triglycerides and haptoglobin are significantly elevated in patients with CVD progression, as measured by thromboembolic events in a two-year follow-up. The findings on haptoglobin may reflect a relationship between inflammation and cardiovascular disease in RA. Neither the levels of platelets nor fibrinogen are associated to event.

* Joint destruction is associated to synovial fluid contents of PAI-1 antigen and, inversely, to plasminogen in RA and SpA. This may implicate an undesirable joint destructive effect of plasmin and other proteolytic enzymes activated for fibrin degradation. Joint destruction also correlates inversely with the plasma level of PAI- 2 antigen.

Apparently, several processes involved in lipid metabolism and haemostasis are influenced in active RA, possibly via cytokines of joint origin. Our results do not provide a consistent explanation to the increased CVD mortality. Some processes seem to be altered towards atherothrombogenesis while others may have a protective function. Thus, the net effect on the atherothrombotic process is difficult to anticipate. The prevalent opinion among rheumatologists is, that early disease modifying treatment of RA is of central importance in preventing joint destruction. However, in the light of the increased death rate due to CVD and IHD in RA, an efficient control of the inflammation should be important, not only to reduce joint destruction but also to reduce atherogenic and thrombogenic systemic effects. The significant positive impact of DMARD treatment on survival in simple Cox regression analysis may be a reflexion of a positive long term effect of treatment that reduces inflammatory activity. Furthermore, no negative effect of corticosteroids on cardiovascular events or death was found in RA. It is possible that the harmful side effects of the drug are outweighed by the benefits of decreased inflammatory activity. 


\section{ACKNOWLEDGEMENTS}

I wish to express my gratitude to all those who in different ways have supported me throughout this project.

Professor Kjell Asplund, Head of the Department of Medicine, for providing me with necessary working facilities, and for stimulating advice.

Associate Professor Solbritt Rantapää Dahlqvist, my supervisor and friend, for guiding me in the wide field of research and for a never ending enthusiasm.

Dr Erik Lundberg, Head of the Department of Rheumatology, for working facilities and support.

Associate Professors Gösta Dahlén and Owe Johnson, co-authors, for valuable criticism and for encouragement.

Associate Professors Gunilla Olivecrona, Mats Rånby, Torbjörn Nilsson and Dr Lars Nordmark, co-authors, for stimulating criticism and support.

Dr Agneta Uddhammar, for all lunch discussions throughout the ups and downs of our common research period.

My collegues at the Department of Rheumatology who took care of my patients when I was absent, and for interest and encouragement.

Marie-Louise Öhman, Ph.D.,co-author, and Professor Hans Nyquist, for invaluable statistical advice.

Drs. Lars Wallinder and Håkan Jonsson, Department of Ortopedics, for all help with the collection of synovial fluid samples.

Gun-Britt Johansson, for invaluable help with the collection of record data and Inger Hamberg, for excellent technical assistance and laboratory work.

Karin Andersson, Ann-Sofie Jakobsson and Gunnel Johansson, for excellent laboratory work.

The staff at the Department of Rheumatology, for collaboration and support in various ways during all these years.

Harmeet Sjögren, Ph.D., for skilful revision of the text. 
Patients and participants in the studies for generous co-operation.

All friends outside my hospital world, for reminding me of other values in life.

My parents and my sisters for giving me a solid basis to stand on in life.

My family; Pelle, Helena, Björn and Mats, for love, patience and encouragement.

This work has been supported by grants from the Faculty of Medicine, University of Umeå, "Borgerskapets i Umeå forskningsstiftelse för Ekonomi, geriatrik och reumatologi", the Medical Research Council, the Bank of Sweden Tercentenary Foundation and "Förenade Liv" Mutual Group Life Insurance Company, Stockholm, Sweden 


\section{REFERENCES}

1. Pincus $\mathrm{T}$, Callahan LF. Taking mortality in rheumatoid arthritis seriously-Predictive markers, socioeconomic status and comorbidity. Editorial. J Rheumatol 1986; 13: 841-5

2. Harris ED. Rheumatoid arthritis. Pathophysiology and implications for therapy. N Engl J Med 1990; 322: 1277-89

3. Duff GW. Cytokines and acute phase proteins in rheumatoid arthritis. Scand J Rheumatol 1994; 23 (Suppl 100): 9-19

4. Goronzy JJ, Weyand CM. T and B cell-dependent pathways in rheumatoid arthritis. Curr Opin Rheum 1995; 7: 214-21

5. Haskard DO. Cell adhesion molecules in rheumatoid arthritis. Curr Opin Rheumatol $1995 ; 7: 229-34$

6. Fassbender HG. Histomorphological basis of articular cartilage destruction in rheumatoid arthritis. Collagen Rel Res 1983; 3: 141-55

7. Zvaifler NJ, Firestein GS. Pannus and pannocytes. Alternative models of joint dstruction in rheumatoid arthritis. Arthritis Rheum 1994; 37: 783-9

8. Müller-Ladner U, Kriegsmann J, Gay RE, Gay S. Oncogenes in rheumatoid arthritis. In: Kremer JM, ed. Rheumatic disease clinics of North America. Philadelphia: WB Saunders, 1995: 675-90

9. Kushner I. The phenomenon of the acute phase response. Ann N Y Acad Sci 1982; 389: $39-48$

10. Emery $\mathrm{P}$, Luqmani $\mathrm{R}$. The validity of surrogate markers in theumatic disease. $\mathrm{Br} \mathrm{J}$ Rheumatol 1993; 32 (Suppl 3): 3-8

11. Sany J. Clinical and immunopathological extra-articular manifestations of rheumatoid arthritis. Rheumatology in Europe 1995; 24 (Suppl 2): 175-8

12. Bacon PA, Kietas GD. The significance of vascular inflammation in rheumatoid arthritis. Editorial. Ann Rheum Dis 1994; 53: 621-3

13. Fitzgerald OM, Barnes L, Woods R, McHugh L, Barry C, O'Loughlin S. Direct immunofluorescence of normal skin in rheumatoid arthritis. Br J Rheumatol 1985; 24: 340-5

14. Flipo R-M, Janin A, Hachulla E, Houvenagel E, Foulet A, Cardon T, Desbonnet A, Grardel B, Duquesnoy B, Delcambre B. Labial salivary gland biopsy assessment in rheumatoid vasculitis. Ann Rheum Dis. 1994; 53: 648-52 
15. Lazarevic MB., Vitic J, Mladenovic V, Myones BL, Skosey J, Swedler WI. Dyslipoproteinemia in the course of active rheumatoid arthritis. Semin Arthritis Rheum 1992; 22: $172-80$

16. Rössner S, Löfmark C. Dyslipoproteinemia in patients with active, chronic polyarthritis. A study on serum lipoproteins and triglyceride clearence (intravenous fat tolerance test). Atherosclerosis 1977; 28: 41-52

17. Svenson KLG, Lithell H, Hällgren R, Selinus I, Vessby B. Altered serum lipoproteins and enhanced lipoprotein elimination in patients with rheumatoid arthritis and other chronic inflammatory arthritides. Arch Intern Med 1987; 147: 1912-6

18. Lorber M, Aviram M, Linn S, Schraf Y, Brook JG. Hypocholesterolemia and abnormal high-density lipoprotein in rheumatoid arthritis. $\mathrm{Br}$ J Rheum 1985; 24: 250-5

19. Hällgren R, Berne C. Glucose intolerance in patients with chronic inflammatory diseases is normalized by glucocorticoids. Acta Med Scand 1983; 213: 351-5

20. Svenson KLG, Lundqvist G, Wide L, Hällgren R. Impaired glucose handling in active rheumatoid arthritis: Relationship to the secretion of insulin and counter-regulatory hormones. Metabolism 1987; 36: 940-3

21. Sörenson JRJ. An evaluation of altered copper, iron, magnesium, manganese and zink concentrations in rheumatoid arthritis. Inorg Perspect Biol Med 1978; 2: 1-26

22. Hällgren $\mathrm{R}$, Svenson $\mathrm{K}$, Johansson $\mathrm{E}$, Lindh U. Abnormal calcium and magnesium stores in erythrocytes and granulocytes from patients with inflammatory connective tissue diseases. Relationship to inflammatory activity and effect of corticosteroid therapy. Arthritis Rheum 1985; 28: 169-73

23. Jacobsson L, Lindgärde F, Manthorpe R, Åkesson B. Correlation of fatty acid composition of adipose tissue lipids and serum phosphatidylcholine and serum concentrations of micronutrients with disease duration in rheumatoid arthritis. Ann Rheum Dis 1990; 49: 901-5

24. Heliövaara M, Knekt P, Aaran R-K, Alfthan G, Aromaa A. Serum antioxidants and risk of rheumatoid arthritis. Ann Rheum Dis 1994; 53: 51-3

25. Pettersson T, Friman C, Nilsson B, Norberg B. Hyperhomocysteinemia in rheumatoid arthritis. Artritis Rheum 1995; 38 (suppl): 366

26. Cobb S, Anderson F, Bauer W. Length of life and cause of death in rheumatoid arthritis. N Engl J Med 1953; 249: 553-6

27. Uddin J, Kraus AS, Kelly HG. Survivorship and death in rheumatoid arthritis. Arthritis Rheum. 1970; 13: 125-30 
28. Isomäki HA, Mutru $\mathrm{O}$, Koota $\mathrm{K}$. Death rate and causes of death in patients with rheumatoid arthritis. Scand J Rheumatol 1975; 4: 205-8

29. Monson RR, Hall AP. Mortality among arthritics. J Cron Dis 1976; 29: 459-67

30. Duthie JJR, Brown PE, Truelove LH, Baragar FD, Lawrie AJ. Course and prognosis in rheumatoid arthritis. A further report. Ann rheum Dis 1964; 23: 193-202

31. Wolfe F, Mitchell DM, Sibley JT, Fries JF, Bloch DA, Williams CA, Spitz PW, Haga M, Kleinheksel SM, Cathey MA. The mortality of rheumatoid arthritis. Arthritis Rheum 1994; 37: 481-94

32. Mutru $\mathrm{O}$, Laakso $\mathrm{M}$, Isomäki $\mathrm{H}$, Koota $\mathrm{K}$. Ten year mortality and causes of death in patients with rheumatoid arthritis. Br Med J 1985; 290: 1811-3

33. Lewis $\mathrm{P}$, Hazleman BL, Hanka R, Roberts S. Cause of death in patients with rheumatoid arthritis with particular reference to azathioprine. Ann Rheum Dis 1980; 39: 45761

34. Allebeck P. Increased mortality in rheumatoid arthritis. Scand J Rheumatol 1982; 11: $81-6$

35. Mitchell DM, Spitz PW, Young DY, Bloch DA, Mc Shane DJ, Fries JF. Survival, prognosis and cause of death in rheumatoid arthritis. Arthritis rheum 1986; 29: 706-714

36. Vandenbroucke JP, Hazevoet HM, Cats A. Survival and cause of death in theumatoid arthritis: A 25-year prospective followup. J Rheum 1984; 11: 158-61

37. Pincus T, Callahan LF, Sale WG, Brooks AL, Payne LE, Vaughn WK. Severe functional declines, work disability, and increased mortality in seventy-five rheumatoid arthritis patients studied over nine years. Arthritis Rheum 1984; 8: 864-72

38. Reilly PA, Cosh JA, Maddison PJ, Rasker JJ, Silman AJ. Mortality and survival in rheumatoid arthritis: a 25 year prospective study of 100 patients. Ann Rheum Dis 1990; 49: $363-9$

39. Prior P, Symmons DPM, Scott DL, Brown R, Hawkins CF. Cause of death in rheumatoid arthritis. Br J Rheum 1984; 23 : 92-9

40. Symmons DPM, Prior P, Scott DL, Brown R, Hawkins CF. Factors influencing mortality in rheumatoid arthritis. J Chron Dis 1986; 39: 137-45

41. Allebeck P, Ahlbom A, Alander E. Increased mortality among patients with rheumatoid arthritis, but where RA does not appear on the death certificate. Scand J Rheumatol 1981; 10: 301-6 
42. Jacobsson LTH, Knowler WC, Pillemar S, Hanson RL, Pettitt DJ, Nelson RG, del Puente A, McCance DR, Charles M-A, Bennett P. Rheumatoid arthritis and mortality. A longitudinal study in Pima Indians. Arthritis Rheum 1993; 36: 1045-1053

43. Linos A, Worthington JW, O'Fallon WM, Kurland LT. The epidemiology of rheumatoid arthritis in Rochester, Minnesota: A study of incidence, prevalence, and mortality. Am J Epidemiol 1980; 111: 87-98

44. Myllykangas-Luosujärvi $\mathrm{R}$, Aho $\mathrm{K}$, Kautiainen $\mathrm{H}$, Isomäki $\mathrm{H}$. Cardiovascular mortality in females with rheumatoid arthritis. J Rheumatol 1995; 22: 1065-7

45. Wood L. Treatment of atherosclerosis and thrombosis with aspirin. Lancet 1972; ii: $532-3$

46. Davies RF, Engelman EG. Incidence of myocardial infarction in patients with rheumatoid arthritis. Arthritis Rheum 1974; 17: 527-533

47. Cathcart ES, Spodick DH. Rheumatoid heart disease. A study of the incidence and nature of cardiac lesions in rheumatoid arthritis. J Med 1962; 266: 959-64

48. Pincus T, Callahan BS. Reassessment of twelve traditional paradigms concerning the diagnosis, prevalence, morbidity and mortality of rheumatoid arthritis. Scand J Rheum 1989; 79 (Suppl): 67-95

49. Bercenovic E, Hurwics M-L. Rheumatoid arthritis and comorbidity. J Rheumatol 1990; 17: 888-892

50. Hansson GK. Immunological control mechanisms in plaque formation. In: Just $H$, Hort W, Zeiher AM, eds. Arteriosclerosis. New insights into pathogenetic mechanisms and prevention. Darmstadt: Steinkopff verlag, 1994: 41-6

51. Ross R. The pathogenesis of atherosclerosis: a perspective for the 1990s. Nature 1993; 362: 801-9

52. Brown MS, Sandip KB, Falck JR, Ho YK, Goldstein JL. The scavenger cell pathway for lipoprotein degradation: Specificity of the binding site that mediates the uptake of negatively-charged LDL by macrophages. J Supramol Struct 1980; 13: 67-81

53. Herz J, Hamann U, Rogne S, Myklebost O, Gausepohl H, Stanley KK. Surface location and high affinity for calcium of a 500-kd liver membrane protein closely related to the LDL-receptor suggests a physiological role as lipoprotein receptor. EMBO J 1988; 7: 411927 
54. Luoma J, Hiltunen T, Särkioja T, Moestrup SK, Gliemann J, Kodama T, Nikkari T, Ylä-Herttuala $S$. Expression of $\alpha_{2}$ macroglobulin receptor/low density lipoprotein receptor related protein and scavenger receptor in human atherosclerotic lesions. J Clin Invest 1994; 93: 2014-21

55. Salonen JT, Ylä-Herttula S, Yamamoto R, Butler S, Korpela H, Salonen R, Nyssönen $\mathrm{K}$, Palinski W, Witztum JL. Autoantibody against oxidised LDL and progression of carotid atherosclerosis. Lancet 1992; 339: 883-7

56. Xu Q, Williet J, Marosi M, Kleindienst R, Oberhollenzer F, Kiechl S, Stulnig T, Luef G, Wick G. Association of serum antibodies to heat-shock protein 65 with carotid atherosclerosis. Lancet 1993; 341: 255-9

57. Falck E. Why do plaques rupture? Circulation 1992; 86 (Suppl III): 30-42

58. Moreno PR, Falk E, Palacios IF, Newell JB, Fuster V, Fallon JT. Macrophage infiltration in acute coronary syndromes. Implications for plaque rupture. Circulation 1994; 90: $775-8$

59. Meyer D, Girma J-P. von Willebrand Factor: Structure and function. Thromb Haemostas 1993; 70: 99-104

60. Bachmann F. Fibrinolysis. In: Varstraete M, Vermylen J, Lijnen HR, Arnout J, eds. Brussels: Thromb Haemost, 1987: 227-65

61. Wiman B, Hamsten A. The fibrinolytic enzyme system and its role in the etiology of thromboembolic disease. Semin Thromb Haemost 1990; 16: 207-16

62. Wallén $P$. Bergsdorf $N$, Rånby $M$. Purification and identification of two structural variants of porcine tissue plasminogen activator by affinity adsorption on fibrin. Biochim Biophys Acta 1982; 719: 318-28

63. Chimliewska $\mathrm{J}$, Rånby $\mathrm{M}$, Wiman $\mathrm{B}$. Evidence for a rapid inhibitor to tissue plasminogen activator in plasma. Thromb Res 1982; 31: 427-36

64. Åstedt B, Lecander I, Ny T. The placental type plasminogen activator inhibitor, PAI2. Fibrinolysis 1987 ; 1: 203-8

65. Mc Mahon S, Peto R, Cutler J, Collins R, Sorlie P, Neaton J, Abbott R, Godwin J, Dyer A, Stamler J. Blood pressure, stroke, and coronary heart disease. Part 1, prolonged differences in blood pressure; prospective observational studies corrected for the regression dilution bias. Lancet 1990; 335: 765-74

66. Turner LW, Lansbury J. Low diastolic pressure as a clinical feature of rheumatoid arthritis and its possible etiologic significance. Am J Med Sci 1954; 227: 503-8 
67. Kaplan D, Ginzler EM, Feldman J. Arthritis and hypertension in patients with systemic lupus erythematosus. Arthritis Rheum 1992; 35: 423-8

68. Kannel WB, D'Agostino RB, Wilson PWF, Belanger AJ, Gagnon DR. Diabetes, fibrinogen, and risk of cardiovascular disease: The Framingham experience. Am Heart J 1990; 120: $672-6$

69. Hakala $\mathbf{M}$, Ilonen J, Reijonen $\mathrm{H}$, Knip $\mathbf{M}$, Koivisto $\mathrm{O}$, Isomäki $\mathrm{H}$. No association between rheumatoid arthritis and insulin dependent diabetes mellitus: An epidemiologic and immunologic study. J Rheumatol 1992; 19: 856-8

70. Svenson KLG, Lundqvist G, Wide L, Hällgren R. Impaired glucose handling in active rheumatoid arthritis: Effects of corticosteroids and anti-rheumatic treatment. Metabolisism 1987; 36: 944-8

71. Kannel WB. Update on the role of cigarette smoking in coronary artery disease. Am Heart J 1981: 319-28

72. Shinton R, Beevers G. Meta-analysis of relation between cigarette smoking and stroke. Br Med J 1989; 298: 789-94

73. Hazes JMW, Dijkmans BAC, Vandenbroucke JP, de Vries RRP, Cats A. Lifestyle and the risk of rheumatoid arthritis: cigarette smoking and alcohol consumption. Ann Rheum Dis 1990; 49: 980-2

74. Voigt LF, Koepsell TD, Nelson JL, Dugowson CE, Daling JR. Smoking, obesity, alcohol consumption and the risk of rheumatoid arthritis. Epidemiology 1994; 5: 525-32

75. Heliövaara M, Aho $\mathrm{K}$, Aromaa A, Knekt P, Reunanen A. Smoking as a risk of rheumatoid arthritis. J Rheumatol 1993; 20: 1830-5

76. Larsson B, Svärdsudd K, Welin L, Wilhelmsen L, Björntorp P, Tibblin G. Abdominal adipose tissue ditribution, obesity, and risk of cardiovascular disease and death: 13 year follow up of participants in the study of men born 1913. Br Med J 1984; 288: 1401-4

77. Salonen JT, Slater JS, Tuomilehto J, Raurmaa R. Leisure time and occupational physical activity: Risk of death from ischemic heart disease. Am J Epidemiol 1988; 127: 8794

78. Kiely DK, Wolf PA, Cupples LA, Beiser AS, Kannel WB. Physical activity and stroke risk: The Framingham study. Am J Epidemiol 1993; 140: 608-20

79. Harkness J. The viscosity of human blood plasma: its measurement in health and disease. Biorheology 1971; 8: 171-93 
80. Ernst E, Resch KL. Fibrinogen as a cardiovascular risk factor: A meta-analysis and review of the litterature. Ann Intern Med 1993; 118: 956-63

81. Eliason M: The epidemiology of fibrinogen and fibrinolysis (Dissertation). Umea, Sweden: Umeå University, 1995, 160p

82. Farr M, Scott DL, Constable TJ, Hawker RJ, Hawkins CF, Stuart J. Thrombocytosis of active rheumatoid disease. Ann Rheum Dis 1983; 42: 545-9

83. Thaulow E, Erikssen J, Sandvik L, Stormorken H, Cohn PF. Blood platelet count and function are related to total and cardiovascular death in apparently healthy men. Circulation 1991; 84: 613-7

84. Ginsburg AD. Platelet function in patients with high platelet counts. Ann Intern Med $1975 ; 82: 506-11$

85. Wahlberg T, Blombäck M, Övermark I. Blood coagulation studies in 45 patients with ischemic cerebrovascular disease and 44 patients with venous thromboembolic disease. Acta Med Scand 1980; 207: 385-90

86. Jansson $\mathrm{JH}$, Nilsson TK, Johnson $\mathrm{O}$. von Willebrand factor in plasma: a novel risk factor for recurrent myocardial infarction and death. Br Heart J 1991; 66: 351-5

87. Hamsten A, Eriksson P. Fibrinolysis and atherosclerosis: an update. Fibrinolysis 1994; 8 (Suppl 1): 253-62

88. Angles-Cano E, Sultan Y, Cluvel J P. Predisposing factors to thrombosis in systemic lupus erythematosus. J Lab Clin Med 1979; 94: 313-323

89. Jordan JM, Bates Allen N, Salvatore VP. Defective release of tissue plasminogen activator in systemic and cutaneous vasculitis. Am J Med 1987; 82: 397-400

90. Belch JJF, Zoma AA, Mc Laughlin K, Forbes CD, Stuurok RD. Vascular damage and factor-VIII-related antigen in the rheumatic diseases. Rheumatol Int 1987; 7: 107-11

91. Mussoni L, Pintucci G, Romano G, De Benedetti F, Massa M, Martini A. Decreased fibrinolytic activity in juvenile chronic arthritis. Ann Rheum Dis 1990; 49: 973-5

92. Nusinow SR, Federici AB, Zimmerman TS, Curd JG. Increased von Willebrand Factor antigen in the plasma of patients with vasculitis. Arthritis Rheum 1984; 27: 1405-10

93. Lau CS, Mc Laren M, Hanslip J, Kerr MJ, Belch JJF. Abnormal plasma fibrinolysis in patients with rheumatoid arthritis and impaired endothelial fibrinolytic response in those complicated by vasculitis. Br J Rheum 1991; Ann Rheum Dis 1993; 52: 643-9 
94. Hart DA, Fritzler MJ. Regulation of plasminogen activators and their inhibitors in rheumatic diseases: New understanding and potential for new directions. J Rheumatol 1989; $16: 1184-91$

95. Mayer M: Biochemical and biological aspects of the plasminogen activation system. Clin Biochem 1990; 23: 197-211

96. Kikuchi H, Tanaka S, Matsuo O. Plasminogen activatior in synovial fluid from patients with rheumatoid arthritis. J Rheumatol 1987; 14: 439-45

97. Brommer E J P, Dooijewaard G, Dijkmans B A C, Breedvald F C. Plasminogen activators in synovial fluid and plasma from patients with arthritis. Ann Rheum Dis 1992; 51: 965-8

98. Kummer J A, Abbing J J, de Boer J-P, Roem D, Nieuwenhuys EJ, Kamp A M, Swaak T J G, Hack C E. Analysis of intraarticular fibrinolytic pathways in patients with inflammatory and noninflammatory joint diseases. Arthritis Rheum 1992; 35: 884-93

99. Saxne T, Lecander I, Geborek P. Plasminogen activators and plasminogen activator inhibitors in synovial fluid. Difference between inflammatory joint disorders and osteoarthritis. J Rheumatol 1993; 20: 91-6.

100. Scandinavian Simvastin Survival Study Group. Randomised trial of cholesterol lowering in 4444 patients with coronary heart disease: the Scandinavian Simvastin Survival Study (4S). Lancet 1994; 344: 1383-9

101. Shepherd J, Cobbe S, Ford I, Isles CG, Lorimer AR, Macfarlane PW, McKillop JH, Packard CJ. Prevention of coronary heart disease with pravastatin in men with hypercholesterolemia. J Med 1995; 333: 1301-7

102. Gordon DJ. Role of circulating high-density lipoprotein and triglycerides in coronary artery disease: Risk and prevention. Endocrin Metab Clin North Am 1990; 19: 299-309

103. Patsch JR, Miesenböck G, Hopferweiser T, Mühlberger V, Knapp E, Dunn JK, Gotto AM, Patsch W. Relation of triglyceride metabolism and coronary artery disease. Studies in the postprandial state. Arterioscler Thromb 1992; 12: 1336-45

104. London MG, Muirden KD. Serum cholesterol in rheumatoid diseases. Br Med J 1963; 1: $1380-3$

105. Dahlén G, Berg K, Ramberg U-B, Tamm A. Lp(a) lipoprotein and pre- $\beta_{1}$-lipoprotein in young adults. Acta Med Scand 1974; 196: 327-31

106. Dahlén GH, Guyton JR, Attar M, Farmer JA, Kautz JA, Gotto AM. Association of levels of lipoprotein (a),plasma lipids and lipoproteins with coronary artery disease documented by angiography. Circulation 1986; 74: 758-65 
107. Rhoads CG, Dahlén GH, Berg K, Morton NE, Dannenberg AL. Lp(a) lipoprotein as a risk factor for myocardial infarction. JAMA 1986; 256: 2540-4

108. Gonzalez-Gronow, Edelberg JM, Pizzo SV. Further characterization of the cellular plsminogen binding site: Evidence that plasminogen 2 and lipoprotein $a$ compete for the same site. Biochemistry 1989; $28: 2374-7$

109. Lascalzo J, Weinfield M, Fless GM, Scanu AM. Lipoprotein (a), fibrin binding, and plasminogen activation. Arteriosclerosis 1990; 10: 240-5

110. Maeda S, Abe A, Seishima M, Makini K, Noma A, Kawade M. Transient changes of serum lipoprotein(a) as an acute phase protein. Atherosclerosis 1989; 78: 145-50

111. Ledue TB, Neveux LM, Palomaki RFR, Craig WY. The relationship between serum levels of lipoprotein(a) and proteins associated with the acute phase response. Clin Chem Acta 1993; 223: 73-82

112. Slunga L, Johnson O, Dahlén GH, Eriksson S. Lipoprotein(a) and acute phase proteins in acute myocardial infarction. Scand J Clin Lab Invest 1992; 52: 95-101

113. Örem A, Deger O, Memis Ö, Bahadir S, Ovali E. Lp(a) lipoprotein levels as a predictor of risk for thrombogenic events in patients with Behcet's disease. Ann Rheum Dis 1995; $54: 726-9$

114. Mc Gregor AJ, Jay RH, Betteridge DJ, Isenberg DA. Serum lipoprotein(a) in SLE. Br J Rheum 1990; 29 (Suppl 2):103

115. Takaheshi S, Yamamoto T, Moriwaki Y, Tsutsumi $\mathrm{Y}$, Higashino $\mathrm{K}$. Increased concentrations of serum $\mathrm{Lp}(\mathrm{a})$ lipoproteins in patients with primary gout. Ann Rheum Dis 1995; 54: 90-93

116. Halliwell B. Oxygen radicals and metal ions: potential antioxidant intervention strategies. In: Cross CE, moderator. Oxygen radicals and human disease. Ann Intern Med. 1987; 107: 526-45

117. Cervera R, Asherson RA, Lie JT. Lipoprotein (a) and anticardiolipin antibodies as risk factors for vascular disease in rheumatoid arthritis. Thromb Haemostas 1995; 74: 799-80

118. Seriolo B, Accardo S, Fasciolo D, Sulli A, Bertolini S, Cutolo M. Lipoprotein(a), anticardiolipin antibodies positivity and thrombotic events in rheumatoid arthritis patients. Rheumatology in Europe 1995; 24 (Suppl 3): 34

119. Lazarevic MB, Vitic J, Myones BL, Mladonevic V, Nunusevic N, Skosey JL, Swedler WI. Antilipoprotein antibodies in rheumatoid arthritis. Semin Arthritis Rheum 1993; 22: 38591 
120. Maxwell SRJ, Moots RJ, Kendall MJ. Corticosteroids: do they damage the cardiovascular system? Postgrad Med J 1994; 70: 863-70

121. Aasen AO, Ruud TE, Pillgram-Larsen J, Röise O, Stadaas J. Modulation of the proteolytic cascade systems by high dose corticosteroids. Acta Chir Scand Suppl 1985; 526: $56-65$

122. Aillaud MF, Juhan-Vague I, Alessi MC, Marecal M, Vinson MF, Arnaud C, Vague P, Collen D. Increased PA-inhibitor levels in the postoperative period-No cause-effect relation with increased cortisol. Thromb Hameostas 1985; 54: 466-8

123. Isacson S. Effect of prednisolone on the coagulation and fibrinolytic systems. Scand J Haemat 1970; 7: 212-6

124. Kalbak K. Incidence of arteriosclerosis in patients with rheumatoid arthritis receiving long-term corticosteroid therapy. Ann Rheum Dis 1972; 31: 196-200

125. Rasker JJ, Cosh JA. Cause and age at death in a prospective study of 100 patients with rheumatoid arthritis. Ann Rheum Dis 1981; 40: 115-20

126. Raynauld J-P, Wolfe F, Sibley JT, Fries JF. Mortality by cardiovascular disease and use of corticosteroids in rheumatoid arthritis. Arthritis Rheum 1993; 36 (suppl): 193

127. Gough A, Lilley J, Eyre S, Holder RL, Emery P. Generalised bone loss in patients with early rheumatoid arthritis. Lancet 1994; 344: 23-7

128. Kirwan JR. The effect of glucocorticoids on joint destruction in rheumatoid arthritis. N Engl J Med 1995; 333: 142-6

129. Petri M, Perez-utthann S, Spencie D, Hochberg MC. Risk factors for coronary artery disease in patients with systemic lupus erythematosus. Am J Med 1992; 93: 513-9

130. Antiplatelet Trialists' Collaboration. Collaborative overview of randomised trials of antiplatelet therapy-I: Prevention of death, myocardial infarction, and stroke by prolonged antiplatelet therapy in various categories of patients. Br Med J 1994; 308: 81-97

131. Svenson K, Lithell H, Hällgren R, Vessby B. Serum lipoproteins in rheumatoid arthritis and other chronic inflammatory artritides. II. Effects of anti-inflammatory and disease modifying drug treatment. Arch Intern Med 1987; 147: 1917-20

132. Wallace DJ, Metzger AL, Stecher VJ, Turnbull BA, Kern PA. Cholesterol-lowering effect of hydroxychloroquine in patients with rheumatoid disease: reversal of deleterious effects of steroids on lipids. A.m J Med 1990; 89: 322-6 
133. Nossen J $\varnothing$, Rustan AC, Barnard T, Drevon CA. Inhibition by chloroquine of the secretion of very low density lipoproteins by cultured rat hepatocytes. Biochem Biophys Acta $1984 ; 803: 11-20$

134. Nilsson J. Lipid oxidation, vascular inflammation, and coronary atherosclerosis. Transpl Proc 1993; 25: 2063-4

135. Toth E, Remes P. Effects of increased depletion of copper, supplementary cholesterol diet and stress on the cholesterol concentration in wall of rat thoracic aorta. Acta Physiol Hung 1994; 82: 125-30

136. Nichols AJ, Vasco JA, Koster PF, Valocik RE, Rhodes GR, Miller-Stein C, Boppana $\mathrm{V}$, Samanen JM. The in vivo pharmacological profile of the novel glycoprotein $\mathrm{IIb} / \mathrm{III}$ antagonist. J pharamacol Exp Ther 1994; 270: 614-21

137. Henriksson $\mathrm{P}$, Edhag $\mathrm{O}$. Orhidectomy vs oestrogen in patients with prostata cancer: Cardiovascular effects. Br Med J 1986; 293: 413-5

138. Stampfer MJ, Colditz GA. Estrogen replacement therapy and coronary disease: A quantitative assessment of the epidemiologic evidence. Prev Med 1991; 20: 47-63

139. Winkler UH. Menopause, hormone replacement therapy and cardiovascular disease: A review of haemostaseological findings. Fibrinolysis 1992; 6 (suppl 3): 5-10

140. Henriksson P, Angelin B, Berglund L. Hormonal regulation of serum Lp(a) levels. J Clin Invest 1992; 89: 1166-71

141. Socialstyrelsen. Klassifikation av sjukdomar 1968. Systematisk förteckning. Stockholm: Liber 197.

142. Ropes MW, Bennet GA, Cobb S. Dignostic criteria for rheumatoid arthritis. Ann Rheum Dis 1959; 18: 49-53

143. Arnett FC, Edworthy SM, Bloch DA, Mc Shane DJ, Fries JF, Cooper NS, Healey LA, Kaplan SR, Liang MH, Luthra HS, Medsger Jr TA, Mitchell DM, Neustedt DH, Pinals RS, Schaller JG, Sharp JT, Wilder RL, Hunder GG. The American Rheumatism Association 1987 revised criteria for the classification of rheumatoid arthritis. Arthritis Rheum 1988; 31: $315-24$

144. Socialstyrelsen: Klassifikation av sjukdomar 1987. Systematisk förteckning. Stockholm: Liber 1986

145. Cooperating Clinics Committee of the American Rheumatism Association. A seven day variability study of 499 patients with peripheral rheumatoid arthritis. Arthritis Rheum 1965; 8: 302-34 
146. Dougados $M$, van der Linden S, Juhlin R, Huitfeldt B, Amor B, Calin A, Cats A, Dijkmans B, Olivieri I, Pasero G, Veys E, Zeidler: The European spondylarthropathy study group preliminary criteria for the classification of spondylarthropathy. Arthritis Rheum 1991; 34: $1218-27$

147. Friedewald WT, Levy RI, Fredrickson DS. Estimation of the concentration of lowdensity lipoprotein cholesterol in plasma without use of the preparative ultracentrifuge. Clin Chem 1972; 18: 499-502

148. Bengtsson-Olivecrona $\mathrm{G}$, Olivecrona $\mathrm{T}$. Lipoprotein analysis. A practical approach. In: C Converse and ER Skinner, eds. Assay of lipoprotein lipase and hepatic lipase. Oxford: IRL Press, 1992; 169-185

149. Vilella E, Joven J, Fernándes M, Vilaró S, Brunzell JD, Olivecrona T, BengtssonOlivecrona G. Lipoprotein lipase in human plasma is mainly inactive and associated with cholesterol-rich lipoproteins. J Lipid Res. 1993; 34: 1555-64

150. Wiman B, Mellbring G, Rånby $M$. Plasminogen activator release during venous stasis and exercise as determined by a new specific assay. Clin Chem Acta 1983; 127: 279-288

151. Eriksson E, Rånby $\mathrm{M}$, Gyzander E, Risberg $\mathrm{B}$. Determination of plasminogen activator inhibitor in plasma using tPA and a chromogenic single-point poly-D-lysine stimulated assay. Thromb Res 1988; 50: 91-101

152. Rånby $\mathrm{M}$, Sundell $\mathrm{IB}$, NIlsson $\mathrm{TK}$. Blood colection in strong acidic citrate anticoagulant used in a study of dietary influence on basal tPA activity. Thromb Haemost 1989; 62: 917-22

153. Rånby $\mathrm{M}$, Eriksson $\mathrm{E}$, Tengborn L, Jonsson-Berg A-K, Risberg B. Fibrinolytic activity in blood characterized by welldefined biochemical parameters; Pro-urokinase is released upon venous occlusion. In: Zilla P, Fasol R, Callow A, eds. Applied Cardiovascular Biology 1989. Basel: Karger, 1990: 124-30

154. Rånby $\mathrm{M}$, Bergsdorf $\mathrm{N}$, Nilsson $\mathrm{T}$, Mellbring $\mathrm{G}$, Winblad $\mathrm{B}$, Bucht $\mathrm{G}$. Age dependence of tissue plasminogen activator concentrations in plasma, as studied by an improved enzyme-linked immunosorbent assay. Clin Chem 1986; 32: 2160-5

155. Cejka J. Enzyme immunoassay for factor VIII-related antigen. Clin Chem 1982; 28 : 1356-1358

156. Larsen A, Dale K, Eek M: Radiographic evaluation of rheumatoid arthritis and related conditions by standard reference films. Acta Radiol Diagn 1977; 18: 481-91

157. Karpe F, Olivecrona $T$, Waldius G, Hamsten A. Lipoprotein lipase in plasma after an oral fat load: relation to free fatty acids. J Lipid Res. 1992; 33: 975-984 
158. Lee ET. Statistical Methods for Survival Data Analysis. In: John Wiley \& Sons, eds. New York. 1992

159. Kaplan EL, Meier P. Nonparametric estimation from incomplete observations. J Am Statist Assoc 1958; 53: 457-81

160. Peto R, Peto J. Asymtomatically efficient rank invariant test procedures (with discussion). J R Statist Soc A; 135: 185-206

161. Cox DR. Regression models and life-tables (with discussion). J R Stat Soc B 1972; 34: $187-220$

162. Norusis I. SPSS for Windows, Advanced Statistics Release 6.1. Marketing Department SPSS Inc. Chicago. 1995

163. Dahlén GH. Incidence of $\mathrm{Lp}$ (a) lipoprotein among populations. In: Scanu AM, ed. Lipoprotein (a). San Diego: Academic press, 1990: 151-73

164. Riise T, Haga H-J, Gran JT, Eide GE, Johansen A. High risk of early death in patients with rheumatoid arthritis in Norway. Rheumatology in Europe 1995; 24 (Suppl 3): 378

165. Pincus T, Callahan LF. The "side effects" of rheumatoid arthritis: Joint destruction, disability and early mortality. Br J Rheum 1993; 32 (suppl 1): 28-37

166. Myllykangas-Luosujärvi $\mathrm{R}$, Aho $\mathrm{K}$, Isomäki $\mathrm{H}$. Death attributed to antirheumatic medication in a nationwide series of 1666 patients with rheumatoid arthritis who have died. $\mathrm{J}$ Rheumatol 1995; 22: 2214-7

167. Lehtinen $\mathrm{K}$, Ismäki $\mathrm{H}$. Intramuscular gold therapy is associated with long survival in patients with rheumatoid arthritis. J Rheumatol 1991; 18: 524-9

168. - Savolainen A, Isomäki HA: Decrease in the number of deaths from secondary amyloidosis in patients with juvenile rheumatoid arthritis. J Rheumatol 1993; 20: 1201-3

169. Svenson K. Endocrine and metabolic aspects of rheumatic disease (Dissertation). Uppsala, Sweden: Uppsala University 1987

170. Brown MS, Goldstein Л. Teaching old dogmas new tricks. Nature 1987; 330: 113-5

171. Zenker G, Költringer P, Boné G, Niederkorn K, Pfeiffer K, Jürgens G. Lipoprotein(a) as a strong indicator for cerebrovascular disease. Stroke; 17: 942-5

172. Gianturco S H, Bradley W A, Dahlén G H, Gaubatz J W, Gotto Jr A M, Morrisett J D, Peavy D L. Interaction of lipoprotein (a) with murine peritoneal macrophages and cultured human fibroblasts. Arteriosclerosis 1983; 3: 500a 
173. Callow MJ, Verstuyft J, Tangirala R, Palinski W, Rubin EM. Atherogenesis in transgenic mice with human apolipoprotein B and lipoprotein (a). J Clin Invest 1995; 96: $1639-46$

174. Eaton DL, Fless GM, Kohr WJ, McLean JW, Xu Qin-tu, Miller CG, Lawn RM, Scanu AM. Partial amino acid sequence of apolipoprotein(a) shows that it is homologous to plasminogen Proc Natl Acad Sci, USA 1987; 84: 3224-8

175. Wade D. Lipoprotein (a). Current opinion in lipidology. 1993; 4: 244-9

176. Morrisett JD, Guyton JR, Gaubatz JW, Gotto Jr AM. Lipoprotein (a): structure, metabolism and epidemiology. In: AM Gotto Jr, ed. Plasma lipoproteins. 1987: 129-52

177. Heinrich J, Sandkamp M, Kokott R, Schulte H, Assmann G. Relationship of lipoprotein (a) to variables of coagulation and fibrinolysis in a healthy population. Clin Chem 1991; 37: 1950-4

178. Boerwinkle E, Leffert C C, Lin J, Lackner C, Chiesa G, Hobbs H. Apolipoprotein(a) accounts for greater than $90 \%$ of the variation in plasma lipoprotein(a) concentrations. J Clin Invest 1992; 90: 52-60

179. Utermann G. The mysteries of lipoprotein (a). Science 1989; 246: 904-10

180. Eisenberg S, Sehayek E, Olivecrona T, Vlodavsky I. Lipoprotein lipase binding of lipoproteins to heparan sulfate on cell surfaces and extracellular matrix. J Clin Invest 1992; 90 : 2013-21

181. Beisiegel U, Weber $W$, Bengtsson-Olivecrona $G$. Lipoprotein lipase enhances the binding of chylomicrons to low density lipoprotein receptor-related protein. Proc Natl Acad Sci USA. 1991; 88: 8342-6

182. Nykjaer A, Bengtsson-Olivecrona G, Lookene A, Moestrup SK, Petersen C, Weber $\mathrm{W}$, Beisiegel U, Gliemann J. The $\alpha-2$ macroglobulin receptor/ low density lipoprotein receptor- related protein binds liporotein lipase and $\beta$-migrating very low density lipoprotein associated with the lipase. J Biol Chem 1993; 268: 15048-55

183. Santamarina-Fojo Silvia, Dugi Klaus. Structure, function and role of lipoprotein lipase in lipoprotein metabolism. Curr Opin Lipidol 1994; 5: 117-25

184. Olivecrona G, Olivecrona T. Triglyceride lipases and atherosclerosis. Curr Opin Lipidol 1995; 6: 291-305

185. Eckel RH. Lipoprotein lipase: a multifunctional enzyme relevant to common metabolic diseases. N Engl J Med 1989; 320: 1060-8 
186. Krapp A, Zhang H, Ginzinger D, Liu M-S, Lindberg A, Olivecrona G, Hayden MR, Beisiegel U. Structural features in lipoprotein lipase necessary for the mediation of lipoprotein uptake into cells. J Lipid Res. In press.

187. Adams DO, Hamilton TA. The cell biology of macrophage activation. Ann Rev Immunol 1984; $2: 283-318$

188. Belch JJF, Mc Ardle B, Madhok R, Mc Laughlin K, Capell HA, Forbes CD, Sturrok RD. decreased plasma fibrinolysis in patients with rheumatoid arthritis. Ann Rheum Dis 1984; 43: 774-7 
